\title{
Nitrous oxide cycling in the Arabian Sea
}

\author{
Hermann W. Bange, Spyridon Rapsomanikis, ${ }^{1}$ and Meinrat O. Andreae \\ Biogeochemistry Department, Max Planck Institute for Chemıstry, Mainz, Germany
}

\begin{abstract}
Depth profiles of dissolved nitrous oxide $\left(\mathrm{N}_{2} \mathrm{O}\right)$ were measured in the central and western Arabian Sea during four cruises in May and July-August 1995 and May-July 1997 as part of the German contribution to the Arabian Sea Process Study of the Joint Global Ocean Flux Study. The vertical distribution of $\mathrm{N}_{2} \mathrm{O}$ in the water column on a transect along $65^{\circ} \mathrm{E}$ showed a characteristic double-peak structure, indicating production of $\mathrm{N}_{2} \mathrm{O}$ associated with steep oxygen gradients at the top and bottom of the oxygen minimum zone. We propose a general scheme consisting of four ocean compartments to explain the $\mathrm{N}_{2} \mathrm{O}$ cycling as a result of nitrification and denitrification processes in the water column of the Arabian Sea. We observed a seasonal $\mathrm{N}_{2} \mathrm{O}$ accumulation at 600-800 m near the shelf break in the western Arabian Sea. We propose that, in the western Arabian Sea, $\mathrm{N}_{2} \mathrm{O}$ might also be formed during bacterial oxidation of organic matter by the reduction of $\mathrm{IO}_{3}{ }^{-}$to $\mathrm{I}^{-}$, indicating that the biogeochemical cycling of $\mathrm{N}_{2} \mathrm{O}$ in the Arabian Sea during the $\mathrm{SW}$ monsoon might be more complex than previously thought. A compilation of sources and sinks of $\mathrm{N}_{2} \mathrm{O}$ in the Arabian Sea suggested that the $\mathrm{N}_{2} \mathrm{O}$ budget is reasonably balanced.
\end{abstract}

\section{Introduction}

Nitrous oxide $\left(\mathrm{N}_{2} \mathrm{O}\right)$ is an atmospheric trace gas that significantly influences, directly and indirectly, Earth's climate. In the troposphere it acts as a greenhouse gas and in the stratosphere it is the major source for NO radicals, which are involved in one of the main ozone reaction cycles [Prather et al., 1996].

Recently published source estimates indicate that the world's oceans play a major, but not dominant, role in the global budget of atmospheric $\mathrm{N}_{2} \mathrm{O}$ [Bouwman et al., 1995; Khalil and Rasmussen, 1992]. Most of the world's ocean surface layer is near gas-exchange equilibrium with the atmosphere [Nevison et al., 1995], whereas a subsurface $\mathrm{N}_{2} \mathrm{O}$ accumulation is generally associated with the oxygen $\left(\mathrm{O}_{2}\right)$ minimum [e.g., Butler et al., 1989; Cohen and Gordon, 1979; Naqvi et al., 1994; Oudot et al., 1990]. Significant $\mathrm{N}_{2} \mathrm{O}$ depletion was observed in water masses showing intense denitrification, that is, anoxic basins [Cohen, 1978; Elkins et al., 1978; Hashimoto et al., 1983; Ronner, 1983] and oxygen depleted (suboxic) water bodies (for an overview see, Codispott et al. [1992]). In most studies of oceanic $\mathrm{N}_{2} \mathrm{O}$, a positive linear correlation between excess $\mathrm{N}_{2} \mathrm{O}\left(\Delta \mathrm{N}_{2} \mathrm{O}=\right.$ $\mathrm{N}_{2} \mathrm{O}$ (observed) - $\mathrm{N}_{2} \mathrm{O}$ (saturated)) and the apparent oxygen utilization (AOU $=\mathrm{O}_{2}$ (saturated) $-\mathrm{O}_{2}$ (observed)) was observed. This led to the prevailing view that during decomposition of organic material in the ocean, nitrification $\left(\mathrm{NH}_{4}^{+} \rightarrow \mathrm{NO}_{2}^{-} \rightarrow\right.$ $\mathrm{NO}_{3}{ }^{-}$) is the main source for oceanic $\mathrm{N}_{2} \mathrm{O}$ [Butler et al., 1989; Cohen and Gordon, 1979; Elkins et al., 1978; Oudot et al., 1990; Yoshinari, 1976]. Based on recent dual-isotope measurements, Dore et al [1998] suggested that $\mathrm{N}_{2} \mathrm{O}$ production via nitrification

\footnotetext{
Now at Laboratory of Atmospheric Pollution Science and Technology, Environmental Engineerıng Department, Demokritos Unıversity of Thrace, Xanthi, Greece.

Copyright 2001 by the American Geophysical Union.

Paper number 1999JC000284

0148-0227/01/1999JC000284\$09.00
}

at the interface of the euphotic-aphotic zone plays an important role in the global tropospheric $\mathrm{N}_{2} \mathrm{O}$ budget. However, from isotope measurements of the $\delta^{15} \mathrm{~N}$ and $\delta^{18} \mathrm{O}$ values of $\mathrm{N}_{2} \mathrm{O}$ in deep water, it is still under debate whether nitrification or denitrification $\left(\mathrm{NO}_{3}^{-} \rightarrow \mathrm{NO}_{2}^{-} \rightarrow \mathrm{N}_{2} \mathrm{O} \rightarrow \mathrm{N}_{2}\right.$ ) is the dominant production pathway in deep water [Kim and Craig, 1990; Yoshida et al, 1989]. At the boundaries of oxygen-depleted water bodies, both nitrification and denitrification or a coupling of both processes may produce $\mathrm{N}_{2} \mathrm{O}$ [Codispoti and Christensen, 1985; Law and Owens, 1990; Naqvi and Noronha, 1991; Naqvi et al., 1998; Upstill-Goddard et al., 1999]. Here we present our measurements of nitrous oxide in the water column of the central and western Arabian Sea during the intermonsoon and southwest (SW) monsoon periods in 1995 and 1997.

\section{Study Area and Sampling Locations}

The northwestern part of the Indian Ocean is defined as the Arabian Sea (Figure 1). It is surrounded by the African and Asian continents to the west, north, and east. The southern boundary is usually set at the equator. The Arabian Sea experiences extremes in atmospheric forcing that lead to the greatest seasonal variability observed in any ocean basin. During the SW monsoon (late May to September), the strongest sustained wind stress is in the highly sheared Findlater Jet. The axis of the Findlater Jet extends generally from northern Somalia to northwestern India. During the SW monsoon, coastal upwelling is driven by Ekman divergence of surface water off shore owing to the influence of winds parallel to the coast. The region of coastal upwelling exists up to $400 \mathrm{~km}$ off the Arabian Peninsula. Downwelling occurs on the southeastern side of the Findlater Jet, driving subduction of surface waters into the thermocline and promoting deepening of the mixed layer.

The Arabian Sea contains diverse biogeochemical features such as eutrophic, oligotrophic, and low-oxygen environments. The latter lies between 150 and $1000 \mathrm{~m}$ depth and represents the thickest oxygen minimum zone (OMZ) found in the world's oceans today. The OMZ of the Arabian Sea is the site of intense denitrification processes and thus plays a major role in the global nitrogen cycle. For further details about the oceanographic and 


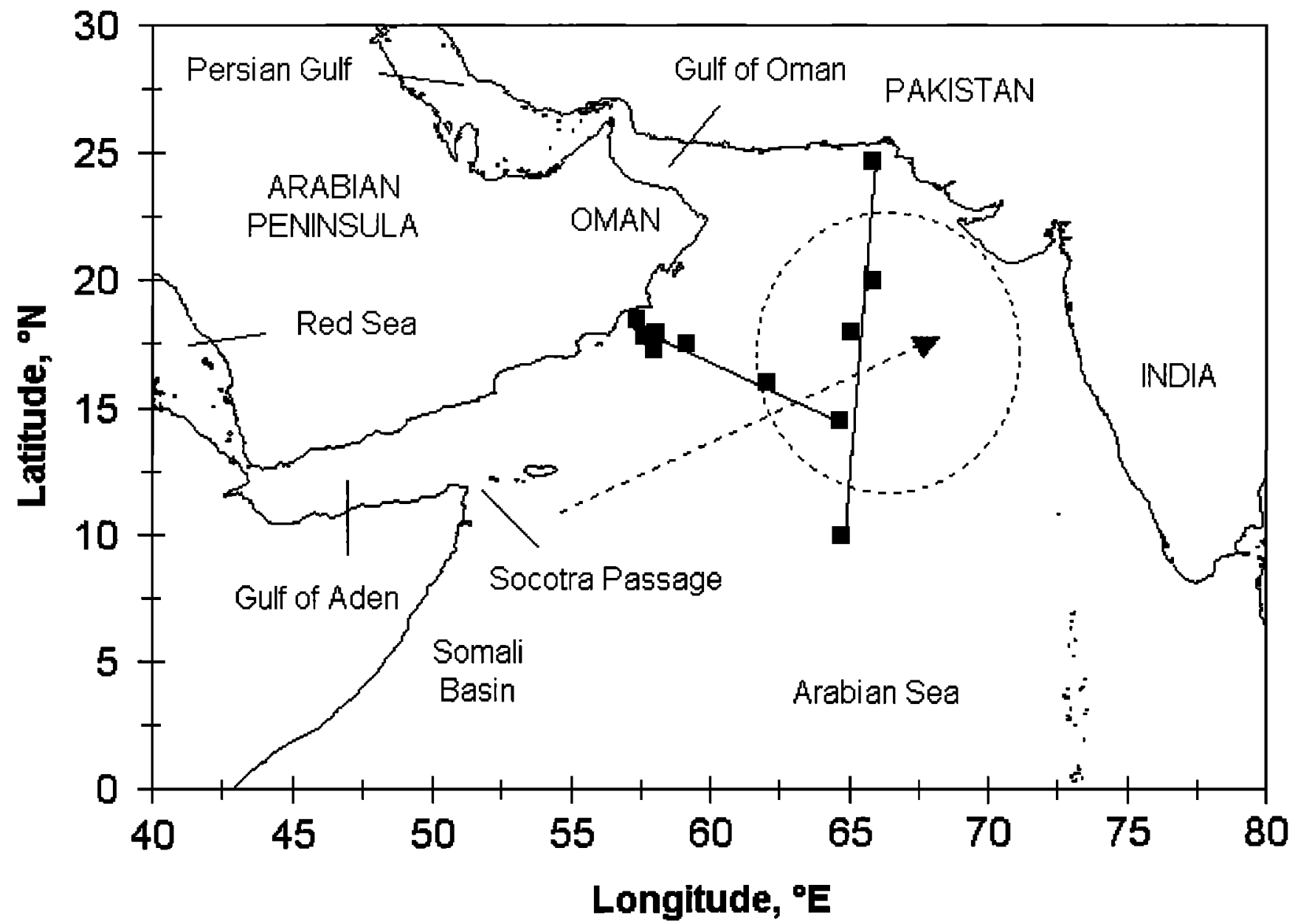

Figure 1. Map of the Arabian Sea with locations of selected stations where $\mathrm{N}_{2} \mathrm{O}$ measurements were performed during the German JGOFS - Arabian Sea Process Study in 1995 and 1997 (for further details see Table 1). The two straight lines indicate the NS and NWSE transects as described in the text. The dashed arrow indicates the axis of the Findlater Jet. The dashed circle indicates the approximate distribution of the core of the denitrification zone as indicated by the secondary nitrite maximum $\left(\mathrm{NO}_{2}^{-}>1 \mu \mathrm{mol} \mathrm{L}^{-1}\right)[\mathrm{Naqvi}, 1994]$.

biogeochemical aspects of the Arabian Sea, the reader is referred to literature compilations presenting results from ongoing international research programs such as the Joint Global Ocean Flux Study (JGOFS) - Arabian Sea Process Study [Burkill, 1999; Burkill et al., 1993; Desai, 1992; Gage et al., 2000; Ittekkot and Nair, 1993; Krishnaswami and Nair, 1996; Lal, 1994; Smith, 1999, 1998; Van Weering et al., 1997]. A comprehensive overview of the historical, geological, hydrographic, chemical, and biological aspects of the Arabian Sea in the context of the Indian Ocean is given in a recently published book by Rao and Griffiths [1998].

The four cruise legs discussed here were part of the German JGOFS - Arabian Sea Process Study and took place on the German research vessels Meteor (M) and Sonne (SO) in May 1995 (leg M32/3), July-August 1995 (leg M32/5), May-June 1997 (leg SO119), and June-July 1997 (leg SO120). Legs $\mathrm{M} 32 / 3, \mathrm{M} 32 / 5$, and SO119 covered mainly the central Arabian Sea, whereas leg SO120 focused on the coastal upwelling area off the Arabian Peninsula (Figure 1).

\section{Method}

Duplicate water samples from various depths were drawn into $100-\mathrm{mL}$ glass flasks from bottles mounted on a rosette water sampler. Flasks with two outlets closed by Teflon valves and one outlet sealed with a silicone rubber septum for headspace sampling (Thermolite ${ }^{\circledR}$, Restek GmbH, Germany) were used. The flasks were rinsed twice with at least two flask volumes of seawater prior to bubble-free filling with the seawater sample. Then $50 \mathrm{~mL}$ of the sample was replaced with helium and the remaining water phase was poisoned with saturated $\mathrm{HgCl}_{2}$ solution (0.2 mL) [Elkins, 1980; Yoshinari, 1976]. Samples were stored at constant room temperature and allowed to equilibrate for at least 2 hours prior to chromatographic analysis. All samples were analyzed within 12 hours after collection. Prior to analysis, the samples were stirred with a magnetic stirrer for $5 \mathrm{~min}$. A 10$\mathrm{mL}$ subsample of the headspace was drawn with a gas-tight glass syringe from the flask and used to purge a thermostated $\left(40^{\circ} \mathrm{C}\right)$, 2-mL sample loop connected to a 10 -port gas stream selecting valve. Then the valve was switched and the sample was injected with the carrier gas onto the column. $\mathrm{N}_{2} \mathrm{O}$ was determined using a gas chromatograph (Model 5890 Series II, Hewlett-Packard, California) equipped with an electron capture detector (ECD). The ECD (Model 19233, Hewlett-Packard, California) was held at a temperature of $350^{\circ} \mathrm{C}$. The analysis was carried out at $190^{\circ} \mathrm{C}$ using a stainless steel column (1.83 m length, $3.2 \mathrm{~mm} \mathrm{OD,}$ $2.2 \mathrm{~mm}$ ID) packed with washed molecular sieve 5A (mesh $80 / 100$, Alltech GmbH, Germany). A mixture of $\mathrm{Ar} / \mathrm{CH}_{4}$ 


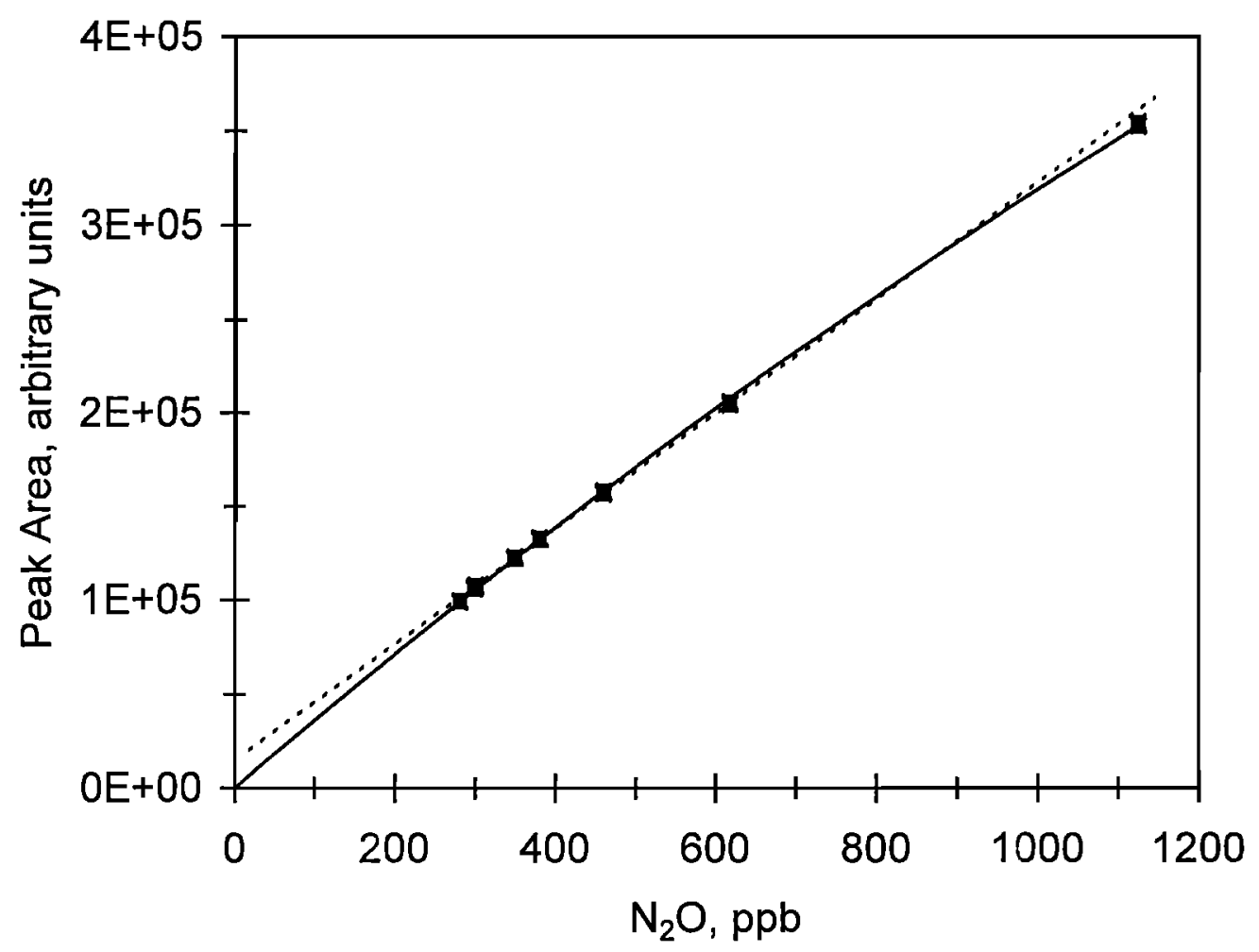

Figure 2. Characteristic response curve of the electron capture detector used in this study. We measured eight calibration gas mixtures: $299.0 \pm 0.2,300.5 \pm 0.1,349.6 \pm 0.2,380.5 \pm 0.3$ (all calibrated against the SIO-1993 standard scale (R. F. Weiss, personal communication, 1996), and $281,460,618$, and $1125 \mathrm{ppb} \mathrm{N}_{2} \mathrm{O}$ in synthetic air $( \pm 2 \%$; Deuste Steininger GmbH, Mühlhausen, Germany). The dashed line represents a linear fit through the points at 300.5 and $349.6 \mathrm{ppb} \mathrm{N}_{2} \mathrm{O}$ (correlation coefficient $r^{2}=0.9977$, number of samples $n=19$ ). The solid line indicates a quadratic fit $\left(y=-0.0458 x^{2}+364.72 x, r^{2}=0.9996\right.$, number of samples $\left.n=47\right)$. Read $4 \mathrm{E}+05$ as $4 \times 10^{5}$.

$(95 \% / 5 \%)$ was used as the carrier gas at a flow rate of $45 \mathrm{~mL} \mathrm{~min}^{-1}$. On a molecular sieve $5 \mathrm{~A}$ column, $\mathrm{CO}_{2}$ elutes after $\mathrm{N}_{2} \mathrm{O}$; the peaks are well separated under the conditions applied [McAllister and Southerland, 1971]. The use of the $\mathrm{Ar} / \mathrm{CH}_{4}$ mixture as carrier gas enhances the ECD sensitivity for $\mathrm{N}_{2} \mathrm{O}$ and, additionally, avoids possible interferences from residual effects in the ECD owing to high $\mathrm{CO}_{2}$ concentrations [Butler and Elkins, 1991].

Mixtures of $\mathrm{N}_{2} \mathrm{O}$ in synthetic air were used to obtain two-point calibration curves. These mixtures contained $300.5 \pm 0.1$ and $349.6 \pm 0.2 \mathrm{ppb} \mathrm{N}_{2} \mathrm{O}$, separately. These are gravimetrically prepared gas mixtures and were calibrated in the laboratory of R. F. Weiss (Scripps Institution of Oceanography (SIO), California), against the SIO-1993 standard scale (R. F.Weiss, personal communication, 1996). To account for the nonlinear ECD response [Butler and Elkins, 1991], we applied a quadratic regression $\left(y=a x^{2}+b x\right)$ for all values $<300 \mathrm{ppb}$ and a linear regression for values $>300 \mathrm{ppb}$. Thus $\mathrm{N}_{2} \mathrm{O}$ values in the range from 350 to $1050 \mathrm{ppb}$, which is above the range covered by the calibration gases, may be overestimated by as much as $2 \%$ owing to the linear regression applied (Figure 2). Concentrations of dissolved $\mathrm{N}_{2} \mathrm{O}$ were calculated as follows:

$$
\begin{aligned}
{\left[\mathrm{N}_{2} \mathrm{O}\right]_{\text {dissolved }} } & =\left[\mathrm{N}_{2} \mathrm{O}\right]_{\text {water sample }}+\left[\mathrm{N}_{2} \mathrm{O}\right]_{\text {headspace }} \\
& =x^{\prime} \beta(T, S) P+x^{\prime} P /(R T)
\end{aligned}
$$

and $x^{\prime}=x /\left(P-p_{\mathrm{H} 2 \mathrm{O}}\right)$, where $x^{\prime}$ is the $\mathrm{N}_{2} \mathrm{O}$ dry mole fraction, $\beta$ is the solubility function [Weiss and Price, 1980], $T$ is the temperature of the sample at the time of the analysis, $S$ is the salinity, $P$ is the atmospheric pressure at the time of the analysis,
$R$ is the gas constant, $x$ is the measured $\mathrm{N}_{2} \mathrm{O}$ wet mole fraction in the headspace, and $p_{\mathrm{H} 2 \mathrm{O}}$ is the water vapor pressure according to Weiss and Price [1980].

To check our method for systematic errors (e.g., efficiency of equilibration), we cross checked the values obtained by the method described above with the data from a well-established automated equilibration system for underway $\mathrm{N}_{2} \mathrm{O}$ measurements in the surface layer. This system was run on board during the same cruises in 1995 and 1997 [Bange et al., 1996, 2000]. The comparison shows a good agreement between both data sets (Figure 3), indicating that systematic errors are mainly introduced by the manual handling of the discrete samples. In order to calculate the theoretical overall analytical precision of our measurements, we assumed typical values and error ranges of $1 \pm 0.05 \mathrm{~atm}, 25 \pm 1^{\circ} \mathrm{C}, 35 \pm 0.1 \%$, and $100 \pm 10 \mathrm{ppb}$ for the pressure, equilibration temperature, salinity, and wet mole fraction, respectively. Computation of the error propagation gave an overall measurement error (i.e., $\Delta\left[\mathrm{N}_{2} \mathrm{O}\right]_{\text {dissolved }}$ ) of $\pm 0.78 \mathrm{nmol} \mathrm{L}^{-1}$. This results in a relative error $\left(\Delta\left[\mathrm{N}_{2} \mathrm{O}\right]_{\text {dissolved }} /\left[\mathrm{N}_{2} \mathrm{O}\right]_{\text {dissolved }}\right)$ of $\pm 12.4 \%$. The computation of $\Delta\left[\mathrm{N}_{2} \mathrm{O}\right]_{\text {dissolved }}$ is most sensitive to errors in pressure, whereas errors of the equilibration temperature and salinity are less important. For example, an error of \pm 0.05 atm for the pressure results in an error of $\pm 7.2 \%$, whereas an error of $\pm 1{ }^{\circ} \mathrm{C}$ results in an error of $\pm 1 \%$ for $\Delta\left[\mathrm{N}_{2} \mathrm{O}\right]_{\text {dissolved. The }}$ precision of the measurements estimated from four replicate samples with an average concentration of $35.2 \mathrm{nmol} \mathrm{L}^{-1}$ was $7.7 \%$. This is in reasonable agreement with the theoretical overall error estimate given above.

Each $\mathrm{N}_{2} \mathrm{O}$ depth profile is a composite of two casts covering different depth ranges collected at the same station within 24 


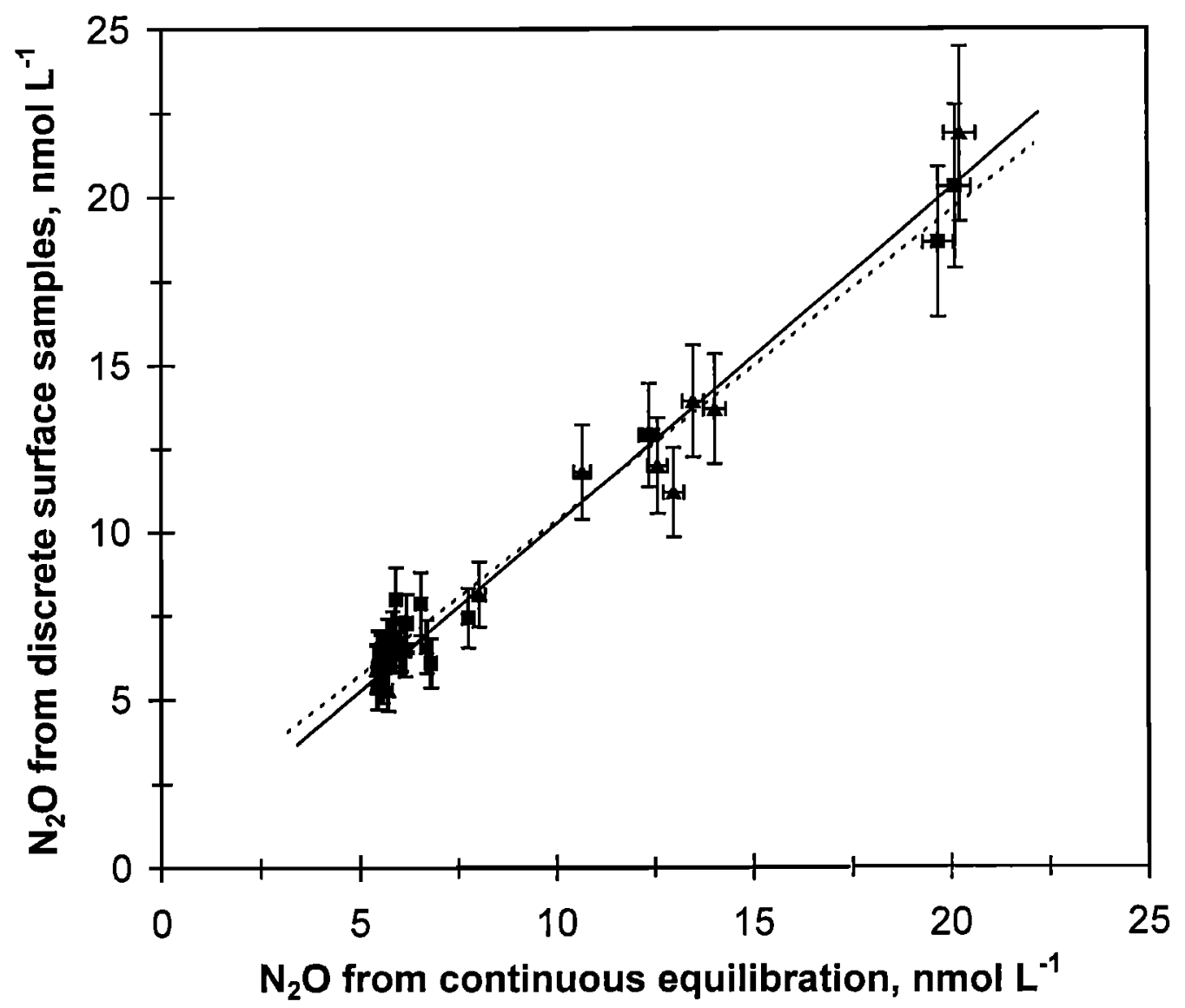

Figure 3. Comparison of $\mathrm{N}_{2} \mathrm{O}$ surface concentrations measured by the discrete sampling method as described in the text (water depths 5-20 m) and a continuous equilibration system (pumping from $7 \mathrm{~m}$ water depth) [Bange at al., 1996]. Solid squares represent data from $M 32 / 3$ and $M 32 / 3$. The dashed line is the linear regression for the data set from M32/3 and M32/5 $\left(y=0.924 x+1.08, r^{2}=0.98, n=12\right)$. Solid triangles represent data from SO119 and SO120. The solid line is the linear regression for the data set from SO119 and SO120 $\left(y=0.997 x+0.26, r^{2}=0.97\right.$, $n=16)$.

hours. Equilibrium concentrations of dissolved $\mathrm{N}_{2} \mathrm{O}$ and $\mathrm{O}_{2}$ were calculated with the equations of Weiss and Price [1980] and Weiss [1970], respectively. We used an atmospheric $\mathrm{N}_{2} \mathrm{O}$ dry mole fraction of $309 \mathrm{ppb}$ [Bange et al., 1996] and $311 \mathrm{ppb}$ $(\mathrm{H}$. W. Bange et al., unpublished data, 2000) for the calculation of the $\mathrm{N}_{2} \mathrm{O}$ equilibrium concentrations in 1995 and 1997 , respectively. Potential seawater temperatures were calculated with the equations listed in Sledler and Peters [1986]. Salinity, in situ water temperature, and nutrient data were taken from data compilations of measurements performed simultaneously to the water sampling (F. Pollehne et al., unpublished data, 1996; B. Zeitzschel et al., unpublished data, 1996, 1998; V. Ittekkot et al., unpublished data, 1998). All data presented are available from the German JGOFS Data Management Office (http://www.ifm.uni-kiel.de/pl/dataman/dmpagl.html).

\section{Results and Discussion}

Some selected stations (Table 1) were grouped into a northsouth (NS) transect from $24.7^{\circ} \mathrm{N}$ to $10^{\circ} \mathrm{N}$ along $65^{\circ} \mathrm{E}$ during the intermonsoon period and into a northwest-southeast (NWSE) transect from $18.5^{\circ} \mathrm{N}, 56.5^{\circ} \mathrm{E}$ to $14.5^{\circ} \mathrm{N}, 65^{\circ} \mathrm{E}$ during the $\mathrm{SW}$ monsoon. (These transects are partly identical with the U.S. JGOFS standard cruise track in the Arabian Sea [Smith, 1998].)
Depth profiles of the dissolved $\mathrm{N}_{2} \mathrm{O}$ and $\mathrm{O}_{2}$ along the NS and NWSE transects are shown in Figures 4 and 5, respectively.

\subsection{NS Transect}

The shapes of the $\mathrm{N}_{2} \mathrm{O}$ profiles from the NS transect from the shelf break off Pakistan $\left(24.7^{\circ} \mathrm{N}\right)$ to the central Arabian Sea $\left(14.5^{\circ} \mathrm{N}\right)$ are clearly associated with the extremely low $\mathrm{O}_{2}$ concentrations $\left(0<\mathrm{O}_{2}<20 \mu \mathrm{mol} \mathrm{L} \mathrm{L}^{-1}\right.$ or expressed in volumetric units $\left.0<\mathrm{O}_{2}<0.25 \mathrm{~mL} \mathrm{~L}^{-1}\right)$ in the $\mathrm{OMZ}$ in the Arabian Sea (Figures $4 \mathrm{~b}-4 \mathrm{~d}$ ). These profiles have a characteristic double-peak structure. In the upper water column a marked increase in the $\mathrm{N}_{2} \mathrm{O}$ concentrations from $5-6 \mathrm{nmol} \mathrm{L}^{-1}$ in the surface layer to about $25-55 \mathrm{nmol} \mathrm{L}^{-1}$ at $150 \mathrm{~m}$ depth forms the first sharp $\mathrm{N}_{2} \mathrm{O}$ peak. This peak is followed by a pronounced depletion of dissolved $\mathrm{N}_{2} \mathrm{O}$ at about $200-500 \mathrm{~m}$ water depth; even undersaturations with concentrations lower than $5 \mathrm{nmol} \mathrm{L}^{-1}$ were observed. This depletion of dissolved $\mathrm{N}_{2} \mathrm{O}$ is most pronounced between $20^{\circ}$ and $18^{\circ} \mathrm{N}$ (Figures $4 \mathrm{c}-4 \mathrm{~d}$ ). $\mathrm{N}_{2} \mathrm{O}$ concentrations increase again up to $60 \mathrm{nmol} \mathrm{L}^{-1}$ at about $800 \mathrm{~m}$ to form the second $\mathrm{N}_{2} \mathrm{O}$ peak (Figures $4 \mathrm{c}-4 \mathrm{e}$ ), followed by a decrease with depth to values of $15 \mathrm{nmol} \mathrm{L} \mathrm{L}^{-1}$ in the deep and bottom waters. The profiles south of $10^{\circ} \mathrm{N}$, which are outside the zone of extreme $\mathrm{O}_{2}$ depletion in the $\mathrm{OMZ}$ as indicated by comparably higher $\mathrm{O}_{2}$ concentrations (Figure 4f), generally showed a 
Table 1. List of the Selected Stations Where $\mathrm{N}_{2} \mathrm{O}$ Measurements Were Performed During the German JGOFS - Arabian Sea Process Study in 1995 and $1997^{\mathrm{a}}$

\begin{tabular}{|c|c|c|c|}
\hline Station & Position & Date & Cruise \\
\hline \multicolumn{4}{|c|}{ NS Transect } \\
\hline EPT & $27.7^{\circ} \mathrm{N}, 65.8^{\circ} \mathrm{N}$ & May 1997 & SO119 \\
\hline NAST & $200^{\circ} \mathrm{N}, 658^{\circ} \mathrm{E}$ & May 1997 & SO119 \\
\hline $\mathrm{D} 1^{\mathrm{b}}$ & $18.0^{\circ} \mathrm{N}, 650^{\circ} \mathrm{E}$ & May 1995 & $\mathrm{M} 32 / 3$ \\
\hline CAST & $145^{\circ} \mathrm{N}, 65.0^{\circ} \mathrm{E}$ & May 1997 & SO119 \\
\hline SAST/D2 & $100^{\circ} \mathrm{N}, 65.0^{\circ} \mathrm{E}$ & May 1997 & SOl19 \\
\hline \multicolumn{4}{|c|}{ NWSE Transect } \\
\hline CAST & $14.5^{\circ} \mathrm{N}, 650^{\circ} \mathrm{E}$ & July 1995 & $\mathrm{M} 32 / 5$ \\
\hline $\mathrm{T} 2$ & $160^{\circ} \mathrm{N}, 62.0^{\circ} \mathrm{E}$ & July 1997 & SO120 \\
\hline T3 & $17.5^{\circ} \mathrm{N}, 59.1^{\circ} \mathrm{E}$ & July 1997 & $\mathrm{SO} 120$ \\
\hline $\mathrm{T} 4$ & $18.1^{\circ} \mathrm{N}, 58.0^{\circ} \mathrm{E}$ & August 1995 & $\mathrm{M} 32 / 5$ \\
\hline T5 & $17.3^{\circ} \mathrm{N}, 57.9^{\circ} \mathrm{E}$ & July 1997 & SO120 \\
\hline T6 & $17.8^{\circ} \mathrm{N}, 57.6^{\circ} \mathrm{E}$ & July 1997 & $\mathrm{SO} 120$ \\
\hline Shelf & $18.5^{\circ} \mathrm{N}, 56.5^{\circ} \mathrm{E}$ & June 1997 & SO120 \\
\hline
\end{tabular}

\footnotetext{
See also Figure 1 .

$\mathrm{b}$ Measurements restricted for the depth range $0-2000 \mathrm{~m}$. The profile is a composite of four casts from various depth ranges.
}

completely different shape of the profile. An accumulation of $\mathrm{N}_{2} \mathrm{O}$ from the surface (up to $37 \mathrm{nmol} \mathrm{L}^{-1}$ between 500 and 1000 $\mathrm{m})$ is followed by a decrease with depth $\left(15 \mathrm{nmol} \mathrm{L}^{-1}\right.$ in the deep and bottom waters) (Figure $4 \mathrm{f}$ ).

Previous measurements of the depth distribution of $\mathrm{N}_{2} \mathrm{O}$ in the Arabian Sea were performed in the central and western regions by Law and Owens [1990] (September-October 1986) and Upstill-Goddard et al. [1999], and in the central and eastern regions by Naqvi and Noronha [1991] (December 1988), Lal et al. [1996], and Patra et al. [1999] (April-May 1994, FebruaryMarch 1995, July-August 1995). There is good agreement between the shapes of previously reported $\mathrm{N}_{2} \mathrm{O}$ profiles and those presented in Figure 4. Both Lal et al. [1996] and Naqvi and Noronha [1991] also describe almost identical double-peak structures for stations in the northern central Arabian Sea (compare Figures $4 \mathrm{~b}$ and $4 \mathrm{c}$ ). However, there might be slight trends for the reported concentrations. Our maximum concentration along the NS transect was $58 \mathrm{nmol} \mathrm{L}^{-1}$ for the second $\mathrm{N}_{2} \mathrm{O}$ peak at $18^{\circ} \mathrm{N}, 65^{\circ} \mathrm{E}$ (Figure $4 \mathrm{~d}$ ), whereas Naqvi and Noronha [1991] and Patra et al. [1999] observed concentrations up to $80 \mathrm{nmol} \mathrm{L}^{-1}$ for the second $\mathrm{N}_{2} \mathrm{O}$ peak at $21.8^{\circ} \mathrm{N}, 64.6^{\circ} \mathrm{E}$ and $18^{\circ} \mathrm{N}, 67^{\circ} \mathrm{E}$. Law and Owens ${ }^{\prime}$ [1990] maximum $\mathrm{N}_{2} \mathrm{O}$ concentration along their NS transect along $67^{\circ} \mathrm{E}$ was $59 \mathrm{nmol} \mathrm{L}^{-}$ ${ }^{1}$ at $14.5^{\circ} \mathrm{N}, 66.9^{\circ} \mathrm{E}$. Undersaturations in the core of the $\mathrm{OMZ}$ (compare Figures $3 \mathrm{c}$ and $3 \mathrm{~d}$ ) were also observed by Law and Owens [1990] and Naqvi and Noronha [1991] but not by Patra et al. [1999].

Comparison of the results from the various studies suggests that the distribution of $\mathrm{N}_{2} \mathrm{O}$ in the central Arabian Sea is only partly known. Differences in the observed $\mathrm{N}_{2} \mathrm{O}$ concentrations might result from the different spatial data coverage and/or temporal (i.e., seasonal and interannual) variability in the Arabian Sea (see also the discussion of the $\Delta \mathrm{N}_{2} \mathrm{O}-\mathrm{AOU}$ relationships below). Profiles of $\mathrm{N}_{2} \mathrm{O}$ typically show an accumulation in the $\mathrm{OMZ}$ of oceanic subsurface layers, most probably owing to nitrification [Dore et al., 1998]. However, when extreme $\mathrm{O}_{2}$ gradients at the boundaries of the $\mathrm{OMZ}$ exist, conditions become ideal for enhanced $\mathrm{N}_{2} \mathrm{O}$ production by nitrification at low $\mathrm{O}_{2}$ concentrations as well as for $\mathrm{N}_{2} \mathrm{O}$ production by denitrification.
Thus the first $\mathrm{N}_{2} \mathrm{O}$ peak observed at approximately $150 \mathrm{~m}$ in the central Arabian Sea might result from a coupling of both [Naqvi et al., 1998; Naqvi and Noronha, 1991]. Recent dual-isotope measurements indicate that denitrification might be the major production pathway for the second $\mathrm{N}_{2} \mathrm{O}$ peak at the lower boundary of the $\mathrm{OMZ}$ in approximately 800-1000 m depth [Naqvi et al., 1998]. The pronounced $\mathrm{N}_{2} \mathrm{O}$ depletion in the core of the OMZ results from $\mathrm{N}_{2} \mathrm{O}$ reduction to $\mathrm{N}_{2}$ during intense denitrification at extremely low $\mathrm{O}_{2}$ concentrations [Naqvi and Noronha, 1991]. Thus we conclude that the $\mathrm{N}_{2} \mathrm{O}$ profiles at the NS transect reflect typical vertical distributions within $\left(>10^{\circ} \mathrm{N}\right.$, Figures $4 \mathrm{~b}-4 \mathrm{e})$ and outside $\left(<10^{\circ} \mathrm{N}\right.$, Figure $\left.4 \mathrm{f}\right)$ the denitrification zone. Our results are in agreement with previously published ideas about the dominating $\mathrm{N}_{2} \mathrm{O}$ production and consumption processes in the central Arabian Sea.

\subsection{NWSE Transect}

The distribution of dissolved $\mathrm{N}_{2} \mathrm{O}$ on the NWSE transect appears to be more complex. The shape of the profile from station CAST (Figure 5b) indicates the characteristic double-peak shape for profiles from the northern part of the NS transect. Going further northwest to station $\mathrm{T} 2$ at $16^{\circ} \mathrm{N}, 62^{\circ} \mathrm{E}$ (Figure $5 \mathrm{c}$ ), the typical upper $\mathrm{N}_{2} \mathrm{O}$ peak at about $150-200 \mathrm{~m}$ was only weakly developed. However, following the transect further to the coast. the double-peak structure was again visible at stations T3, T4, and $\mathrm{T} 5$ (Figures $5 \mathrm{~d}-5 \mathrm{f}$ ). The $\mathrm{N}_{2} \mathrm{O}$ profile at the shelf break off Oman (Figure $5 \mathrm{~g}$ ) is similar to the one observed at the shelf break off Pakistan (Figure 5f); however, the concentrations are higher at the coast off Oman. The highest concentrations (up to $64 \mathrm{nmol}$ $\mathrm{L}^{-1}$ ) during the German JGOFS cruises were observed at $700 \mathrm{~m}$ depth at station $\mathrm{T} 4\left(18^{\circ} \mathrm{N}, 58^{\circ} \mathrm{E}\right)$ (Figure $5 \mathrm{e}$ ). Over the shelf with water depths of about $80 \mathrm{~m}$, dissolved $\mathrm{N}_{2} \mathrm{O}$ accumulates from 20 $\mathrm{nmol} \mathrm{L} \mathrm{L}^{-1}$ in the surface layer to $40 \mathrm{nmol} \mathrm{L}^{-1}$ in the bottom layer (Figure 5h). The results of Law and Owens [1990] and UpstillGoddard et al. [1999] also showed high $\mathrm{N}_{2} \mathrm{O}$ concentrations (up to $\Delta \mathrm{N}_{2} \mathrm{O}$ of $104 \mathrm{nmol} \mathrm{L}^{-1}$ [Law and Owens, 1990]) in the western Arabian Sea, which are as high as those from the central Arabian Sea. Recently published $\mathrm{N}_{2} \mathrm{O}$ profiles by Upstill-Goddard et al. [1999] from a similar NWSE transect, which was located north of the German JGOFS transect, are in general agreement with ours.

The temporal development of the distributions of $\mathrm{N}_{2} \mathrm{O}$ and $\mathrm{O}_{2}$ on the NWSE transect during three cruises in July-August 1995, May 1997 and June-July 1997 is shown in Plate 1. Using data from two different years may introduce a bias owing to a possible interannual variability; however, since we will focus on a qualitative rather than a quantitative interpretation our approach might be reasonable. The $\mathrm{O}_{2}$ depleted layer $\left(<20 \mu \mathrm{mol} \mathrm{L}{ }^{-1}\right)$ extends to the shelf of the Arabian Peninsula, showing only a modest temporal variation (Plates $1 \mathrm{~d}-1 \mathrm{f}$ ). In contrast, the $\mathrm{N}_{2} \mathrm{O}$ concentrations show a considerable seasonal signal (Plates la1c). While during May 1997 (Plate la), an $\mathrm{N}_{2} \mathrm{O}$ plume originating from the central Arabian Sea is visible, the situation during the early stage of the SW Monsoon (June-July 1997, Plate 1b) and during the fully developed SW Monsoon (JulyAugust 1995, Plate 1c) is completely different. During the SW Monsoon the development of a strong local source of $\mathrm{N}_{2} \mathrm{O}$ near the shelf break at $700 \mathrm{~m}$ depth (corresponding to a potential density $\left(\sigma_{\theta}\right)$ of 27.3$)$ is obvious. Either an in situ source (e.g., denitrification) or a seasonally occurring boundary current transporting $\mathrm{N}_{2} \mathrm{O}$-enriched water might be the reason for the observed enhanced $\mathrm{N}_{2} \mathrm{O}$ concentrations:

1. Water mass analysis indicated that Red Sea water with a 

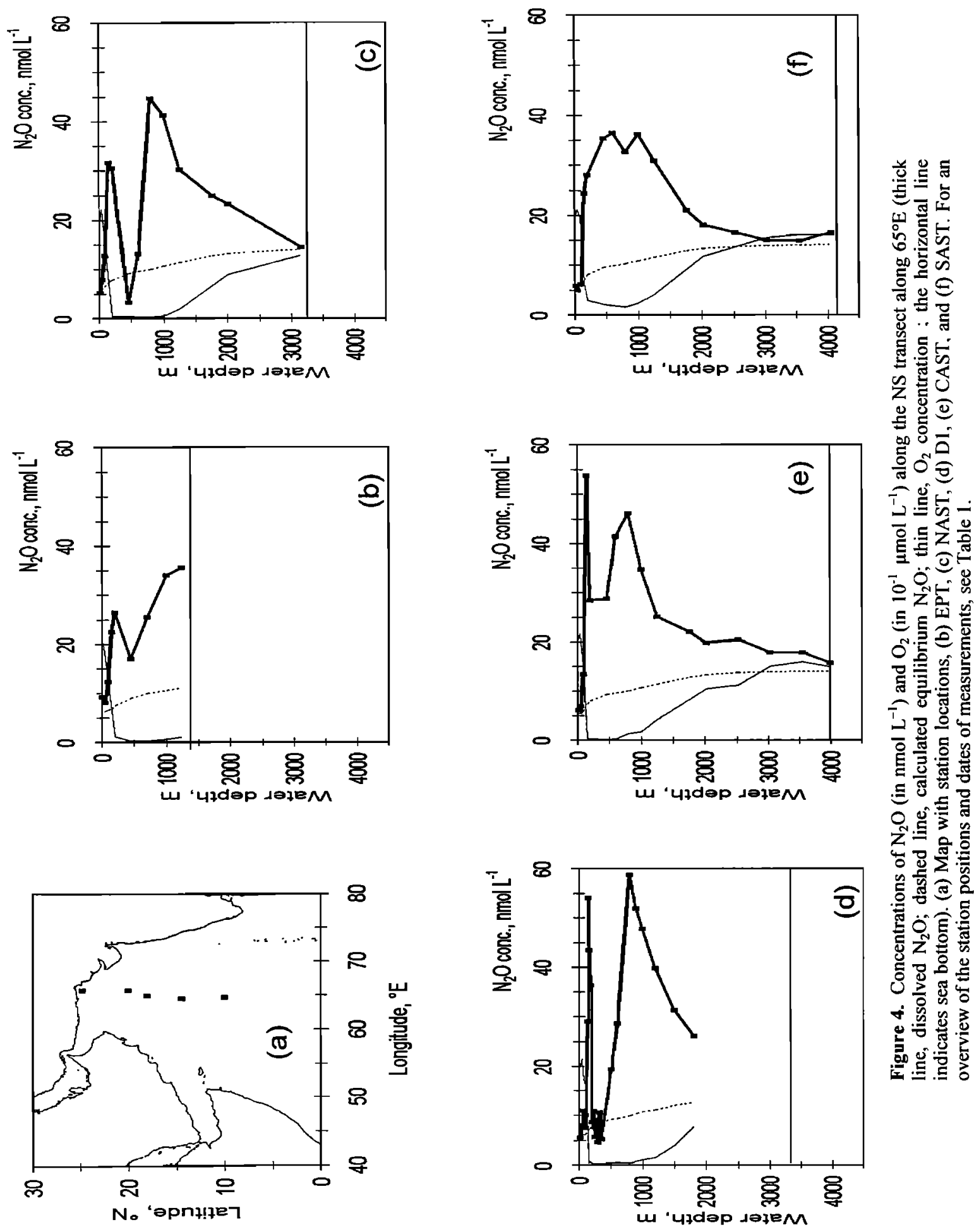

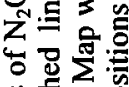

น

웡

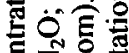

记

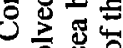

+ 的

可

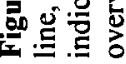



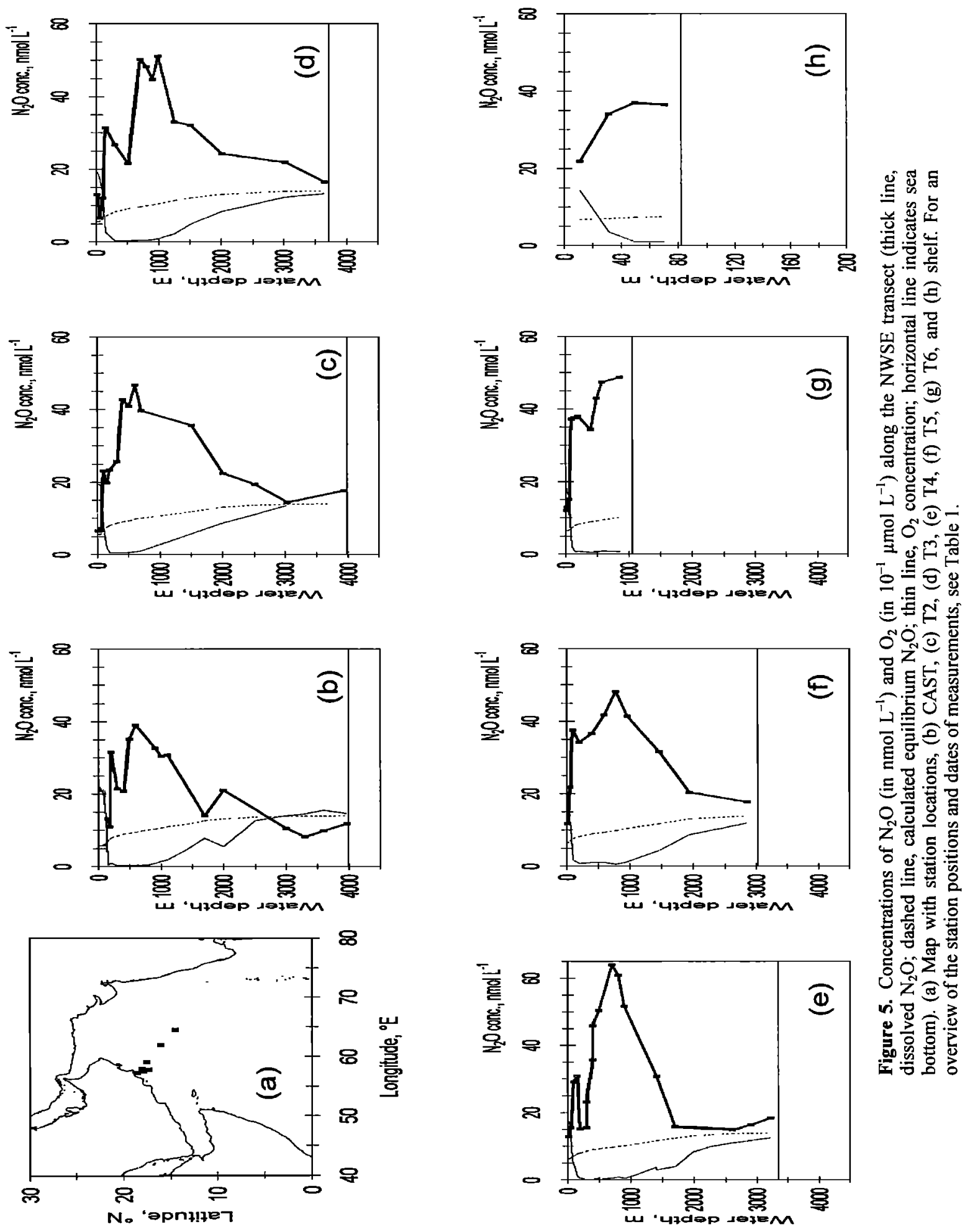

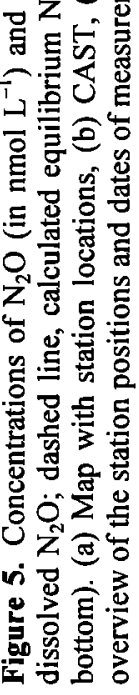


core $\sigma_{\theta}$ of 27.2 at $600-700 \mathrm{~m}$ was not detectable, probably because its inflow to the Arabian Sea is usually blocked during the SW Monsoon [Morrison et al., 1998; Shenot et al, 1993]. Instead, we can speculate that an inflow of $\mathrm{N}_{2} \mathrm{O}$-enriched water from the Somali Basin [De Wilde and Helder, 1997] through the Socotra Passage might occur [Schott et al., 1997; You, 1997].

2. The $\mathrm{O}_{2}$ concentrations in the $\mathrm{OMZ}$ on the NWSE transect were depleted in $\mathrm{O}_{2}$, comparable to those in the central Arabian Sea and favoring conditions for denitrification. However, the $\mathrm{OMZ}$ of the western Arabian Sea is not characterized by the permanent secondary nitrite $\left(\mathrm{NO}_{2}^{-}\right)$maximum [Morrison et al., 1998], which is often used as an indicator for the occurrence of denitrification [Naqvi, 1991].

Interestingly, Farrenkopf et al. [1997] found extremely high subsurface maxima of iodide $\left(\mathrm{I}^{-}\right)$near the Arabian Peninsula (around $17^{\circ} \mathrm{N}, 57^{\circ} \mathrm{E}$ ) at $600-800 \mathrm{~m}$ depth $\left(\sigma_{\theta}=27.3-27.5\right)$. They concluded that, within the $\mathrm{OMZ}$, organic matter decomposition via bacterial reduction of iodate $\left(\mathrm{IO}_{3}^{-}\right)$to $\mathrm{I}^{-}$could be as important as denitrification. A possible decomposition of organic matter via oxidation by $\mathrm{IO}_{3}{ }^{-}$to yield $\mathrm{N}_{2} \mathrm{O}$ might be written as follows:

$81.3 \mathrm{IO}_{3}^{-}+\left(\mathrm{CH}_{2} \mathrm{O}\right)_{106}\left(\mathrm{NH}_{3}\right)_{16} \mathrm{H}_{3} \mathrm{PO}_{4}$

$$
\rightarrow 81.3 \mathrm{I}^{-}+106 \mathrm{CO}_{2}+8 \mathrm{~N}_{2} \mathrm{O}+130 \mathrm{H}_{2} \mathrm{O}+\mathrm{H}_{3} \mathrm{PO}_{4} \text {. }
$$

Following the concept of Froelich et al. [1979] ( $\Delta G^{\circ}$ data were taken from Stumm and Morgan [1996]), we calculated for the reaction given above a $\Delta G^{\circ}=-2712 \mathrm{~kJ}$ per mole glucose, which is comparable with $\Delta G^{\circ}$ values given for the oxidation of organic matter by $\mathrm{IO}_{3}^{-}$yielding $\mathrm{NH}_{3}\left(-2605 \mathrm{~kJ} \mathrm{~mol}^{-1}\right), \mathrm{HNO}_{3}(-$ $\left.2804 \mathrm{~kJ} \mathrm{~mol}^{-1}\right)$, or $\mathrm{N}_{2}\left(-3047 \mathrm{~kJ} \mathrm{~mol}^{-1}\right)$ [Farrenkopf et al., 1997]. Despite the fact that the $\mathrm{I}^{-}$data from Farrenkopf et al. [1997] are from the transition from the SW monsoon to the intermonsoon (October 1992) and might be therefore not representative for the peak of SW monsoon (July-August), we speculate that the observed enhanced $\mathrm{N}_{2} \mathrm{O}$ concentrations might be coupled to a bacterially mediated $\mathrm{IO}_{3}{ }^{-} / \mathrm{I}^{-}$cycle. The mean decomposition of particulate organic matter between 505 and $809 \mathrm{~m}$ water depth at U.S. JGOFS station $S 2\left(18.1^{\circ} \mathrm{N}, 58^{\circ} \mathrm{E}\right)$ measured during the spring intermonsoon and SW monsoon 1995 was about $1.5 \mu \mathrm{mol}$ $\mathrm{C} \mathrm{m}^{3} \mathrm{~d}^{-1}$ [Lee et al., 1998]. Converting this with the molar ratio of $\mathrm{N}_{2} \mathrm{O}$ to organic carbon of $8 / 106$ (see equation above) yields a theoretical $\mathrm{N}_{2} \mathrm{O}$ production of $0.113 \mu \mathrm{mol} \mathrm{m} \mathrm{m}^{-1}$. From our measurements we estimated an accumulation of $\mathrm{N}_{2} \mathrm{O}$ between 500 and $800 \mathrm{~m}$ of about $20 \mathrm{nmol} \mathrm{L}^{-1}$ from May to August (Plates 1a1c). Assuming that this accumulation is representative for the time interval of the organic flux measurements (204 days), we estimated the $\mathrm{N}_{2} \mathrm{O}$ production to be about $0.098 \mu \mathrm{mol} \mathrm{m}^{3} \mathrm{~d}^{-1}$. Thus the observed $\mathrm{N}_{2} \mathrm{O}$ accumulation is slightly lower than the theoretically predicted $\mathrm{N}_{2} \mathrm{O}$ production, indicating that the decomposition of organic carbon via the $\mathrm{IO}_{3}^{-} / \mathrm{I}^{-}$mechanism might contribute to the $\mathrm{N}_{2} \mathrm{O}$ production. However, it is very unlikely that almost all organic carbon is converted to $\mathrm{N}_{2} \mathrm{O}$. More likely a mixture of $\mathrm{N}_{2} \mathrm{O}$ and more energetically favored products (e.g., $\mathrm{N}_{2}$ ) will occur. We conclude that there is not yet a satisfactory explanation for the local source of $\mathrm{N}_{2} \mathrm{O}$ at the shelf break in the western Arabian Sea; neither an inflow event nor enhanced $\mathrm{N}_{2} \mathrm{O}$ production via denitrification or other mechanisms have been substantiated.

\section{3. $\triangle \mathrm{N}_{2} \mathrm{O}-\mathrm{AOU}$ Relationship}

As mentioned in the introduction, a positive correlation between $\Delta \mathrm{N}_{2} \mathrm{O}$ and $\mathrm{AOU}$, indicating $\mathrm{N}_{2} \mathrm{O}$ formation via

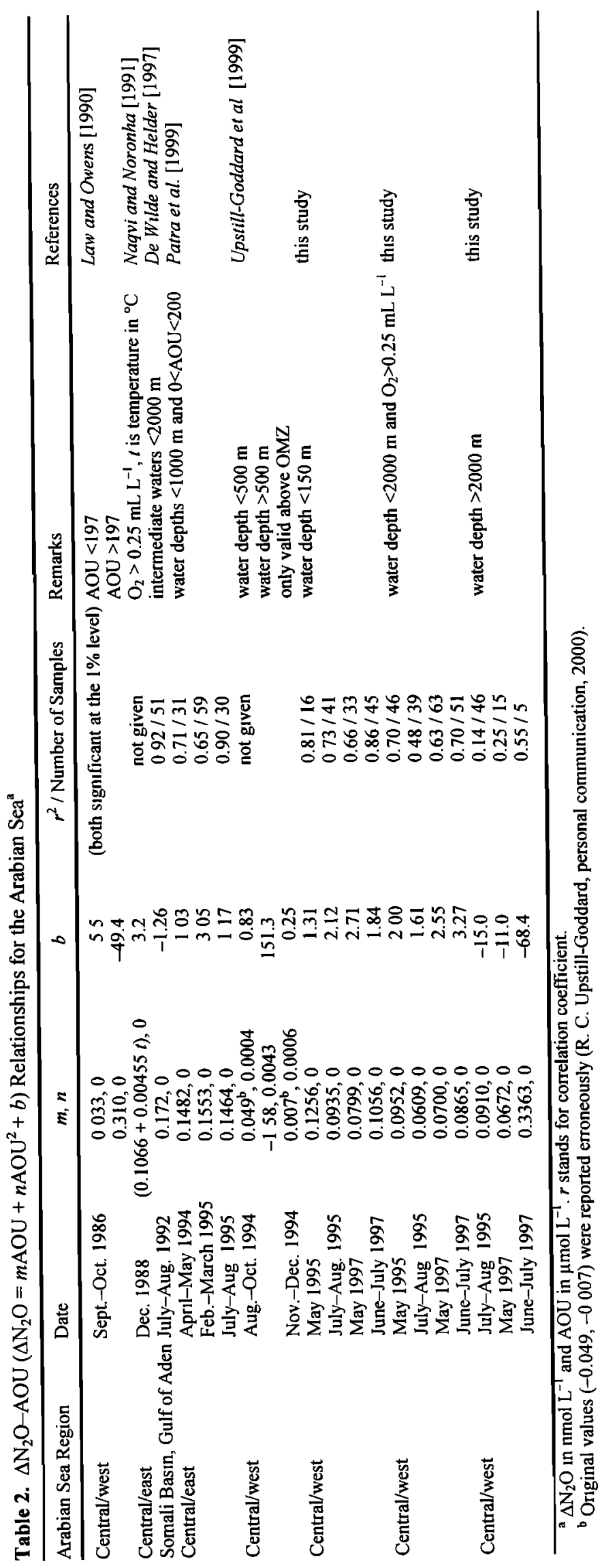


Table 3. Rates of $\mathrm{N}_{2} \mathrm{O}$ Production in the OMZ $\left(\mathrm{O}_{2}<0.25\right.$ $\mathrm{mL} \mathrm{L}^{-1}$ ) of the Central Arabian Sea

\begin{tabular}{lcc}
\hline & $\begin{array}{c}\text { Integrated } \Delta \mathrm{N}_{2} \mathrm{O}^{2}, \\
\mathrm{Tg} \mathrm{N} \mathrm{N}_{2} \mathrm{O}\end{array}$ & $\begin{array}{c}\text { Range of } \mathrm{N}_{2} \mathrm{O} \text { Production Using } \\
\text { 1-/10-Year Ventilation Tıme, } \\
\mathrm{Tg} \mathrm{N}_{2} \mathrm{O} \mathrm{yr}^{-1}\end{array}$ \\
\hline May 1995 & 2.5 & $2.5 / 0.25$ \\
July-Aug. 1995 & $1.9 \pm 0.5$ & $1.9 / 019$ \\
May 1997 & $1.6 \pm 03$ & $1.6 / 0.16$ \\
June-July 1997 & $24 \pm 0.5$ & $2.4 / 024$ \\
Average & 2.1 & $2.1 / 0.21$ \\
\hline
\end{tabular}

\footnotetext{
${ }^{a}$ Calculated as mean vertical integrated $\Delta \mathrm{N}_{2} \mathrm{O}$ times area of the $\mathrm{OMZ}$ affected by denitrification $\left(1.95 \times 10^{12} \mathrm{~m}^{2},[\mathrm{Naqvi}, 1991]\right)$.

${ }^{b}$ One-year ventilation time according to Naqvi and Shaulaja [1993]; 10-year ventilation time according to Olson et al [1993]
}

nitrification, is found in a variety of oceanic environments. An overview of previously published $\triangle \mathrm{N}_{2} \mathrm{O}-\mathrm{AOU}$ relationships for the Arabian Sea together with those calculated on the basis of our $\mathrm{N}_{2} \mathrm{O}$ data is presented in Table 2 . In a recent study, UpstillGoddard et al [1999] showed that a second-order polynomial gave the best statistical fit to their data from the western and central Arabian Sea. We found considerable differences between the various $\triangle \mathrm{N}_{2} \mathrm{O}$-AOU relationships. Even for data from the same year and season (e.g., July-August 1995, Table 2), the values differ considerably and could be explained only by a different spatial data coverage. Seasonal or interannual trends might be obscured in the data for various reasons, such as the difference in the yield of $\mathrm{N}_{2} \mathrm{O}$ production owing to the composition and the amount of organic matter to be oxidized or to an additional $\mathrm{N}_{2} \mathrm{O}$ source, e.g., assimilatory nitrate reduction [Elkins et al., 1978]. Assimilatory nitrate reduction $\left(\mathrm{NO}_{3}{ }^{-} \rightarrow\right.$ $\mathrm{NO}_{2}{ }^{-} \rightarrow \mathrm{NH}_{4}{ }^{+}$) was proposed by some authors as a possible source of $\mathrm{N}_{2} \mathrm{O}$ in nitrate-enriched waters, e.g., in upwelling regions; however, this hypothesis has never been proved [Oudot et al., 1990; Pierotti and Rasmussen, 1980]. Most $\Delta \mathrm{N}_{2} \mathrm{O}-\mathrm{AOU}$ relationships for the Arabian Sea are based on data sets excluding data affected by denitrification in the $\mathrm{OMZ}$ (i.e., $\mathrm{O}_{2}<0.25 \mathrm{~mL} \mathrm{~L}^{-}$ $\left.{ }^{1}\right)$. This indicates a shift in the pathways of $\mathrm{N}_{2} \mathrm{O}$ production from nitrification to denitrification in the $\mathrm{OMZ}$ of the central Arabian Sea, which can not be represented by the common $\Delta \mathrm{N}_{2} \mathrm{O}-\mathrm{AOU}$ relationship. The situation is even more complicated because $\mathrm{N}_{2} \mathrm{O}$ can also be consumed during denitrification, leading to low $\mathrm{N}_{2} \mathrm{O}$ values in the core of the $\mathrm{OMZ}$ in the central Arabian Sea. Despite the fact that the $\Delta \mathrm{N}_{2} \mathrm{O}-\mathrm{AOU}$ relationships for deep water $(>2000$ $\mathrm{m}$ ) are statistically not significant, they all show similar positive trends comparable to those observed for the upper ocean (Table 2). Thus we can speculate that nitrification is still the main pathway for $\mathrm{N}_{2} \mathrm{O}$ production, but it might be balanced by subsequent $\mathrm{N}_{2} \mathrm{O}$ reduction via denitrification as proposed by Kim and Craig [1990].

\section{4. $\mathrm{N}_{2} \mathrm{O}$ Budget for the Arabian Sea}

To obtain knowledge of the $\mathrm{N}_{2} \mathrm{O}$ production in the Arabian Sea, we estimated $\mathrm{N}_{2} \mathrm{O}$ production for the $\mathrm{OMZ}$ affected by denitrification $\left(\mathrm{O}_{2}<0.25 \mathrm{~mL} \mathrm{~L}^{-1}\right)$ (Table 3). For this purpose we calculated the $\mathrm{N}_{2} \mathrm{O}$ column abundances, defined as the vertically integrated profile of $\Delta \mathrm{N}_{2} \mathrm{O}$. With the mean $\Delta \mathrm{N}_{2} \mathrm{O}$ calculated for each leg, it is possible to estimate the net $\mathrm{N}_{2} \mathrm{O}$ production within the $\mathrm{OMZ}$, assuming an area for the denitrification of $1.95 \times 10^{12}$ $\mathrm{m}^{2}$ [Naqvi, 1991] and a ventilation time of 1-10 years [Naqvi and Shailaja, 1993; Olson et al., 1993]. The applied OMZ area affected by denitrification is $30 \%$ higher than the revised value of $1.37 \times 10^{12} \mathrm{~m}^{2}$ recently proposed by Naqvi [1991]. However, using a larger area appears more appropriate to account for the area distribution of the $\mathrm{N}_{2} \mathrm{O}$ production processes (see discussion of the NWSE transect above). Moreover, the considerable range in the $\mathrm{OMZ}$ ventilation times (1-11 years) reported in the literature (for a discussion see Naqvi [1994]) introduces a more significant uncertainty.

Annual $\mathrm{N}_{2} \mathrm{O}$ production in the $\mathrm{OMZ}$ was previously calculated to be $0.4 \mathrm{Tg}$ by Mantoura et al. [1993] on the basis of the 1986 data set of Law and Owens [1990]. However, Mantoura et al. [1993] used a 10-year ventilation time; thus their value can be considered as a lower limit. Applying a ventilation time of 1 year scales their value up to $4 \mathrm{Tg} \mathrm{N}_{2} \mathrm{O} \mathrm{yr}^{-1}$. A comparison with our results $\left(0.2-2 \mathrm{Tg} \mathrm{N}_{2} \mathrm{O} \mathrm{yr}^{-1}\right.$, Table 3$)$ reveals that the results are in reasonable agreement, despite possible biases due to seasonal and interannual variabilities. We calculated a mean $\mathrm{N}_{2} \mathrm{O}$ production in the $\mathrm{OMZ}$ of $1.1 \mathrm{Tg} \mathrm{yr}^{-1}$ (i.e., $0.7 \mathrm{Tg} \mathrm{N} \mathrm{yr}^{-1}$ ) which represents about $2 \%$ of the mean pelagic denitrification of about $33 \mathrm{Tg} \mathrm{N} \mathrm{yr}^{-}$ ${ }^{1}$ [Bange et al., 2000].

Table 4. $\mathrm{N}_{2} \mathrm{O}$ Budget for the Arabian Sea North of $6^{\circ} \mathrm{N}$

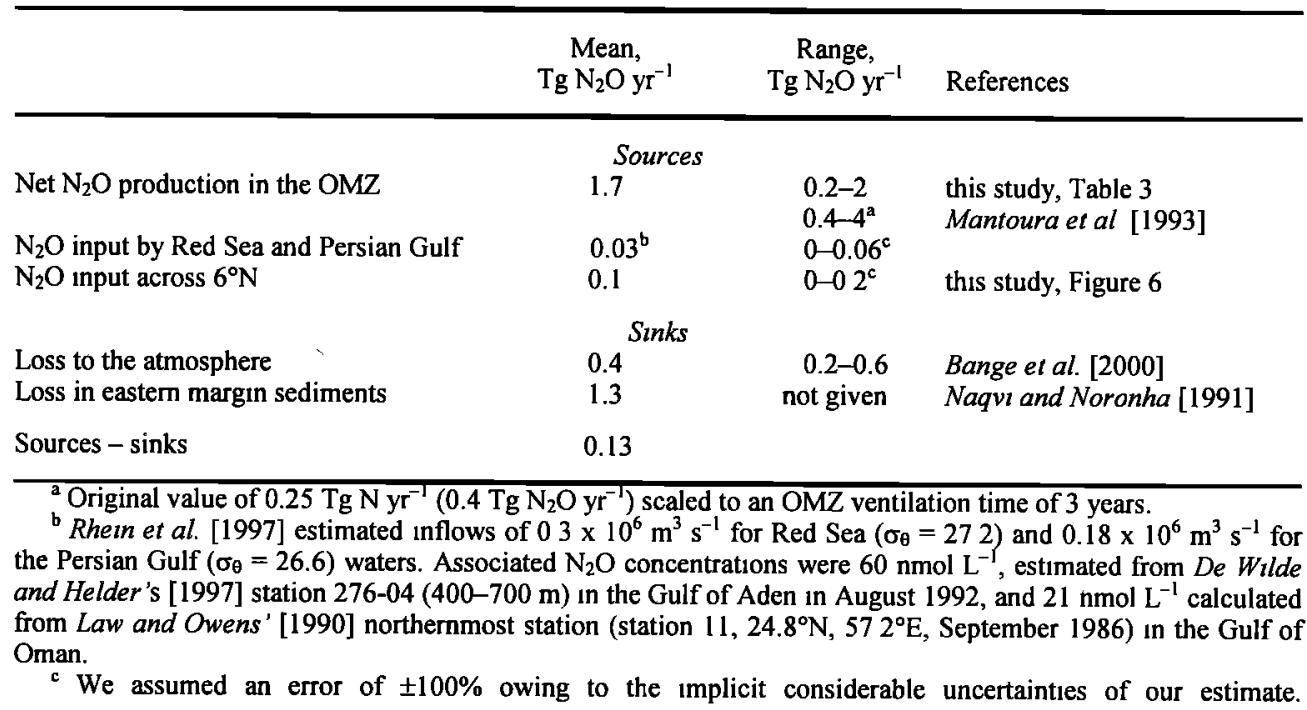



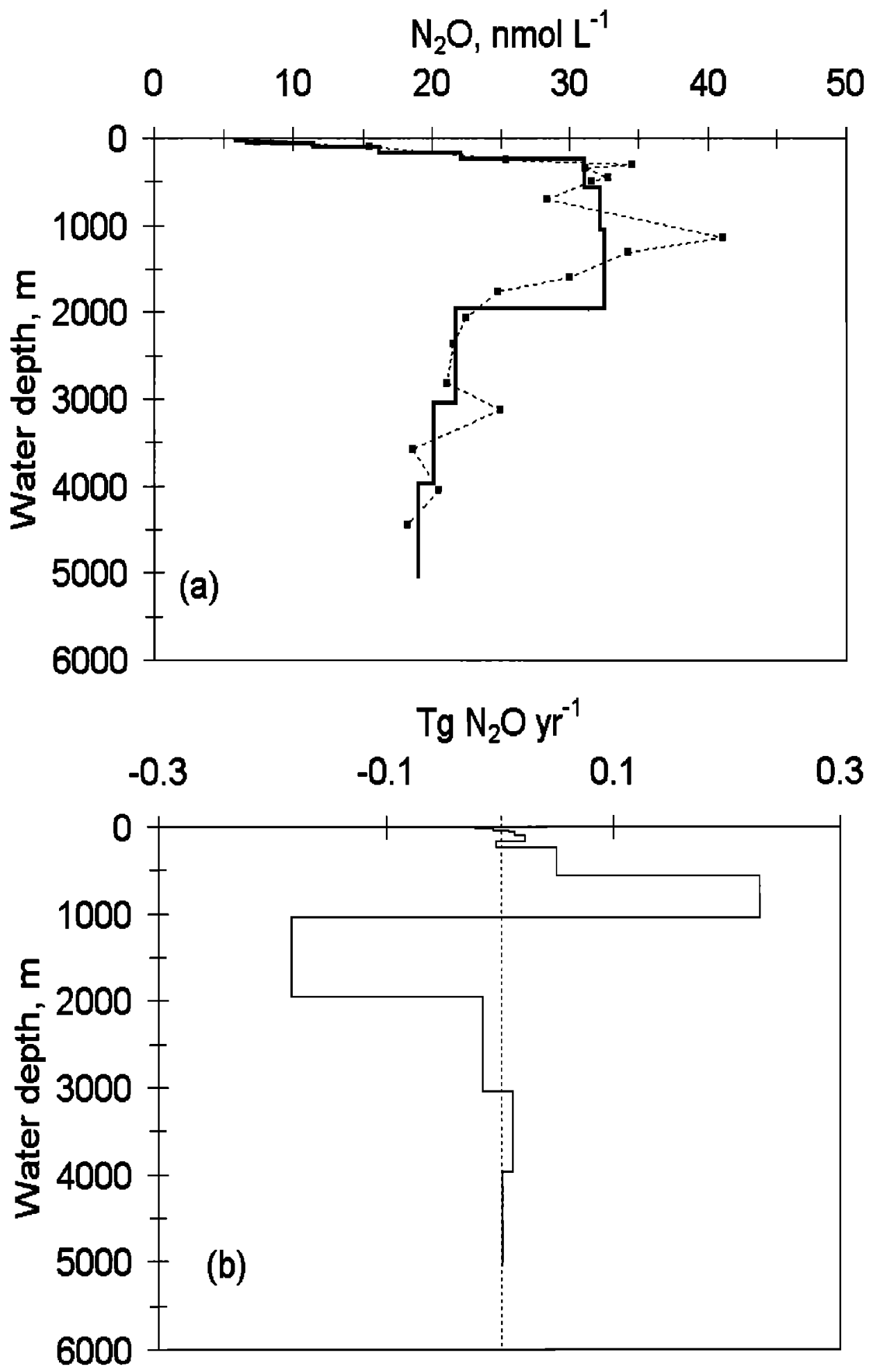

Figure 6. $\mathrm{N}_{2} \mathrm{O}$ flux into and out of the Arabian Sea along $6^{\circ} \mathrm{N}$ : (a) $\mathrm{N}_{2} \mathrm{O}$ concentrations (dashed line, $\mathrm{N}_{2} \mathrm{O}$ profile at $6^{\circ} \mathrm{N}, 65^{\circ} \mathrm{E}$ in July 1995 during cruise $\mathrm{M} 32 / 5$; solid line, calculated standard level mean $\mathrm{N}_{2} \mathrm{O}$ profile). (b) Resulting mean annual $\mathrm{N}_{2} \mathrm{O}$ flux for the layers of the GCM (negative values represent outflows and positive values represent inflows into the Arabian Sea across $6^{\circ} \mathrm{N}$ ).

An overall $\mathrm{N}_{2} \mathrm{O}$ budget for the Arabian Sea based on the data presented here and found in the literature is presented in Table 4. In order to obtain consistent $\mathrm{N}_{2} \mathrm{O}$ flux estimates we adopted the approach used by Bange et al. [2000] for a revision of the nitrogen fluxes of the Arabian Sea. The southern boundary of the
Arabian Sea was set to $6^{\circ} \mathrm{N}$ spanning a line from the Somali coast to the southem tip of Sri Lanka (for details see Bange et al. [2000]).

In order to assess the mean annual $\mathrm{N}_{2} \mathrm{O}$ exchange across the southern boundary of the Arabian Sea at $6^{\circ} \mathrm{N}$, monthly values for 
(a)

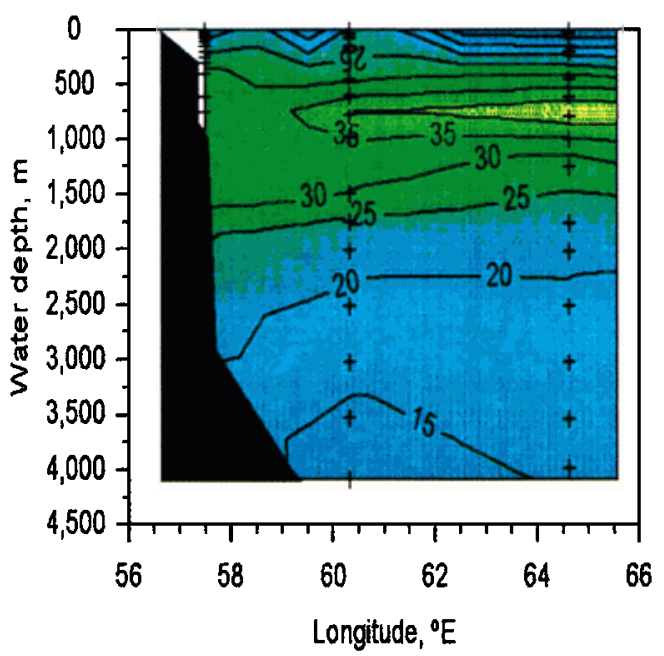

(b)

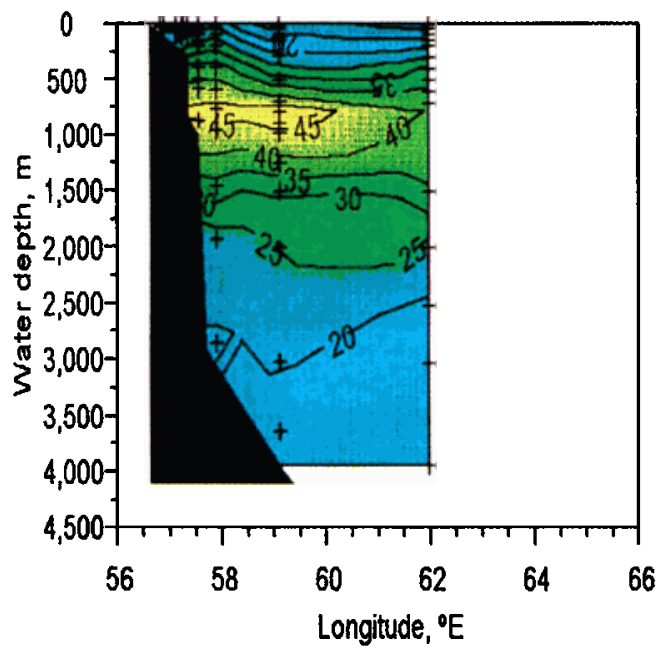

(c)

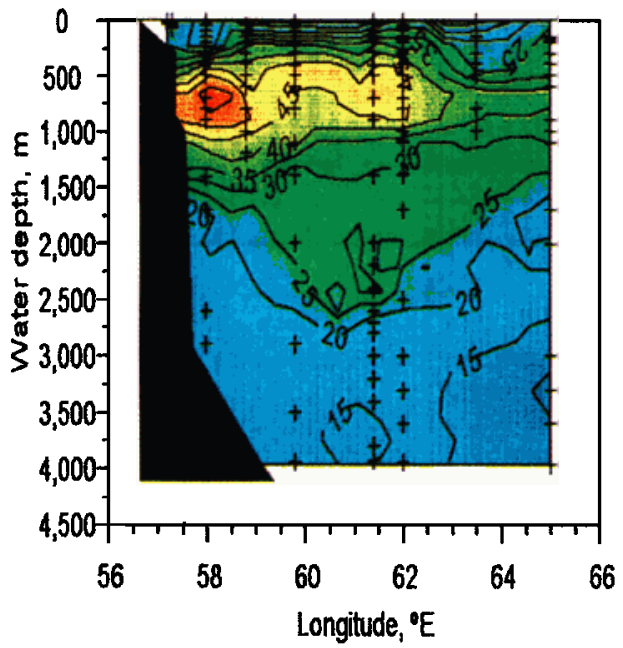

(d)

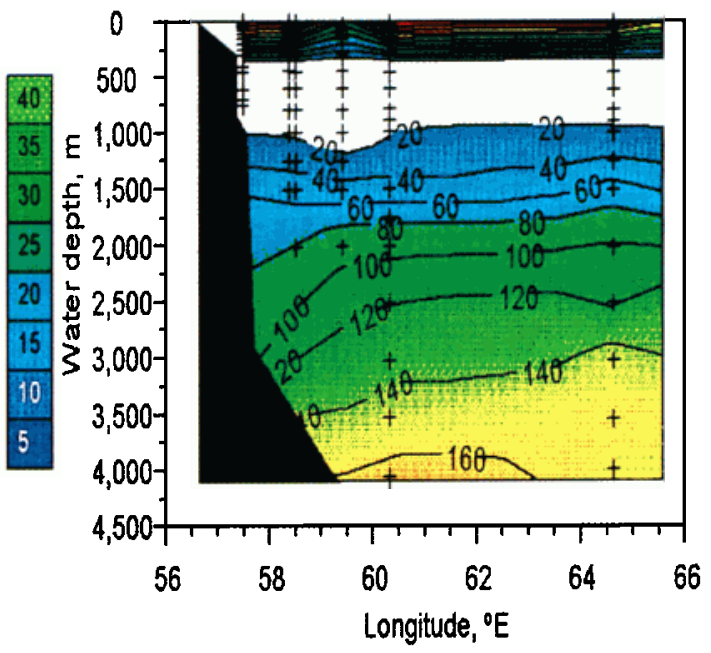

(e)

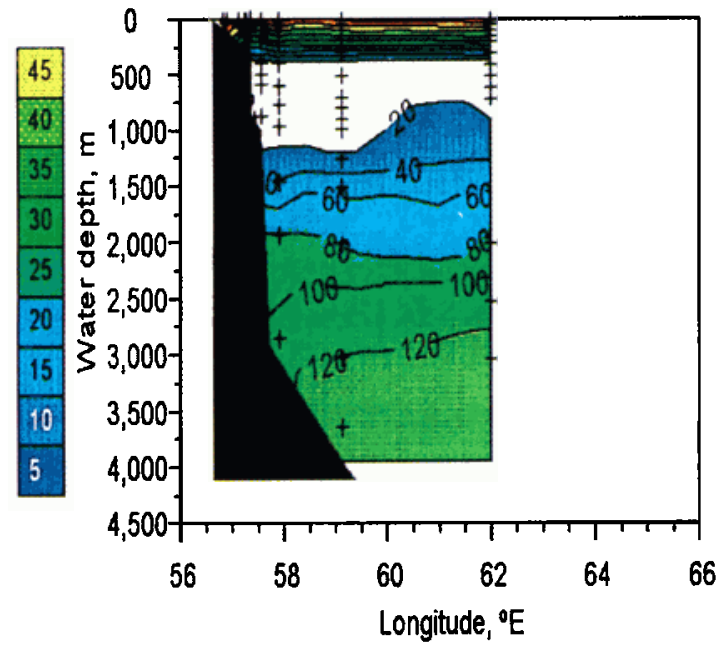

(f)

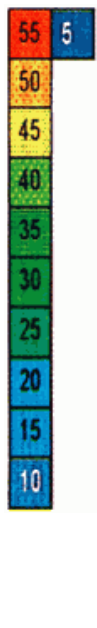

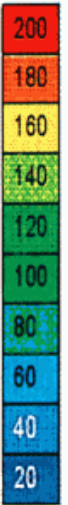

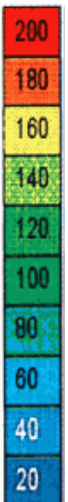

20

Plate 1. Concentrations of $\mathrm{N}_{2} \mathrm{O}$ (in $\mathrm{nmol} \mathrm{L} \mathrm{L}^{-1}$ ) and $\mathrm{O}_{2}$ (in $\mu \mathrm{mol} \mathrm{L} \mathrm{L}^{-1}$ ) along the NWSE transect in the western Arabian Sea. (left), $\mathrm{N}_{2} \mathrm{O}$ : (a) May 1997, (b) June-July 1997, and (c) July-August 1995. (right), $\mathrm{O}_{2}$ (white areas indicate concentrations below $20 \mu \mathrm{mol} \mathrm{L}^{-1}$ ): (d) May 1997, (e) June-July 1997, and (f) July-August 1995. 
the water transport across $6^{\circ} \mathrm{N}$ were extracted from a general circulation model (GCM) consisting of 13 depth layers with a $1^{\circ}$ $\times 1^{\circ}$ horizontal resolution (for details see Bange et al. [2000]). $\mathrm{N}_{2} \mathrm{O}$ values were taken from a profile at $6^{\circ} \mathrm{N}, 65^{\circ} \mathrm{E}$ (July 1995 , $\mathrm{M} 32 / 5$ ). The $\mathrm{N}_{2} \mathrm{O}$ concentrations were scaled to the grid points of the GCM (Figure 6a). Then we calculated for each grid point the mean annual $\mathrm{N}_{2} \mathrm{O}$ flux. Summing the fluxes yields the net $\mathrm{N}_{2} \mathrm{O}$ fluxes for each layer (Figure 6b). The resulting overall net flux sums up to an annual input into the Arabian Sea of about $0.1 \mathrm{Tg}$ $\mathrm{N}_{2} \mathrm{O}$. The major sink for $\mathrm{N}_{2} \mathrm{O}$ in the Arabian Sea is its consumption in eastern margin sediments and the major source is the $\mathrm{N}_{2} \mathrm{O}$ production in the OMZ. Inputs by Red Sea and Persian Gulf waters as well as advective input from the south appear to play only a minor role. The budget from the data in Table 4 seems to be reasonably balanced. However, the magnitude of the sedimentary $\mathrm{N}_{2} \mathrm{O}$ loss is under debate. As discussed by Naqvi et al. [1992], the observed $\mathrm{N}_{2} \mathrm{O}$ gradients at the eastern margin sediments could also result from advective processes, indicating an overestimation of the $\mathrm{N}_{2} \mathrm{O}$ sink in the sediments. Moreover, our estimate of the $\mathrm{N}_{2} \mathrm{O}$ emissions to the atmosphere might be too low since recent $\mathrm{N}_{2} \mathrm{O}$ measurements in the upwelling region off southwestern India during the $\mathrm{SW}$ monsoon showed extremely high $\mathrm{N}_{2} \mathrm{O}$ concentrations [Naqvi et al, 1998], which may lead to an upward revision of the current $\mathrm{N}_{2} \mathrm{O}$ emission estimates.

\section{Conclusions}

A compilation of sources and sinks of $\mathrm{N}_{2} \mathrm{O}$ in the Arabian Sea suggested that the $\mathrm{N}_{2} \mathrm{O}$ budget is reasonably balanced. In view of our results, we propose a rough scheme of $\mathrm{N}_{2} \mathrm{O}$ production and consumption pathways in the Arabian Sea. Our scheme consists of four compartments that could explain the characteristic double-peak structure of $\mathrm{N}_{2} \mathrm{O}$ in the Arabian Sea:

Compartment $1,0-150 \mathrm{~m}: \mathrm{N}_{2} \mathrm{O}$ is mainly produced by nitrification as indicated by the $\Delta \mathrm{N}_{2} \mathrm{O}-\mathrm{AOU}$ relationships (Table 2). However, isotope data measured by Naqvi et al. [1998] revealed that nitrification may not be the only source. $\mathrm{N}_{2} \mathrm{O}$ may also be produced via coupling of nitrification and denitrification associated with the steep $\mathrm{O}_{2}$ gradient at the top of the $\mathrm{OMZ}$, forming the sharp $\mathrm{N}_{2} \mathrm{O}$ peak at about $150 \mathrm{~m}$ [Naqvi et al., 1998].

Compartment 2, 150-1000 m: $\mathrm{N}_{2} \mathrm{O}$ consumption occurs at $300-500 \mathrm{~m}$ (i.e., the denitrifying core of the OMZ) of the central Arabian Sea. At the lower boundary of the OMZ at about 800 $1000 \mathrm{~m}, \mathrm{~N}_{2} \mathrm{O}$ seems to be mainly produced by denitrification when the $\mathrm{O}_{2}$ concentrations are increasing again [Naqvi et al., 1998].

Compartment 3, 1000-2000 m: In the central Arabian Sea the denitrification signal (i.e., $\delta^{15} \mathrm{~N}$ of $\mathrm{NO}_{3}{ }^{-}$) is assumed to be mixed down to a depth of at least $1500 \mathrm{~m}$ owing to ventilation processes such as cross-isopycnal mixing [Brandes et al., 1998]. This implies that $\mathrm{N}_{2} \mathrm{O}$ produced at the bottom of the $\mathrm{OMZ}$ is also mixed down by cross-isopycnal mixing, forming the broad second $\mathrm{N}_{2} \mathrm{O}$ peak. $\triangle \mathrm{N}_{2} \mathrm{O}-\mathrm{AOU}$ relationships (excluding data affected by denitrification) are reasonably valid from $0-2000 \mathrm{~m}$ (Table 2) Thus we can conclude that nitrification contributes significantly to the $\mathrm{N}_{2} \mathrm{O}$ production throughout the water column; however, the $\mathrm{N}_{2} \mathrm{O}$ produced by denitrification results in less clear $\Delta \mathrm{N}_{2} \mathrm{O}-\mathrm{AOU}$ relationships.

Compartment 4, below $2000 \mathrm{~m}$ : No statistically significant $\Delta \mathrm{N}_{2} \mathrm{O}-\mathrm{AOU}$ relationship was found. $\mathrm{N}_{2} \mathrm{O}$ produced by nitrification may be reduced subsequently by denitrification [ $\mathrm{Kim}$ and Cralg, 1990].

This scheme may also be valid for the western Arabian Sea; however, owing to the seasonal variability of the complex hydrographic situation (e.g., coastal upwelling, inflow of marginal sea water), the $\mathrm{N}_{2} \mathrm{O}$ double-peak structure is not wellestablished. Furthermore, we have some indication that $\mathrm{N}_{2} \mathrm{O}$ at $600-800 \mathrm{~m}$ near the shelf break in the western Arabian Sea is formed via a different process such as oxidation of organic matter by reduction of $\mathrm{IO}_{3}^{-}$to $\mathrm{I}^{-}$, indicating that the biogeochemical cycling of $\mathrm{N}_{2} \mathrm{O}$ in the central and western Arabian Sea during the SW Monsoon is more complex than previously thought.

Acknowledgments. We thank G. Schebeske and our glass blower B. Beickler for their invaluable assistance. We acknowledge the help of many other colleagues and the officers and crews of the R/V Meteor and R/V Sonne. Thanks are due to the chief scientists F. Pollehne (M32/3), B. Zeitzschel (M32/5 and SO120), and V. Ittekkot (SO119) Special thanks are due to the team of the R/V Sonne scientific-technical service for their support on board. We are indebted to many colleagues for their generosity in sharing data. We especially thank $\mathrm{C} \mathrm{S}$ Law for providing his $\mathrm{N}_{2} \mathrm{O}$ data from the 1986 Arabian Sea expedition We thank C. Strametz for help with the manuscript. We gratefully acknowledge $J \mathrm{M}$. Lobert and two anonymous reviewers for their constructive criticisms of the manuscript. The investigations were financially supported by the German Bundesminısterium für Bildung, Wissenschaft, Forschung und Technologie through grants 03F0137A, 03F0183G, 03F0241C and by the Max Planck Society.

\section{References}

Bange, H.W., S. Rapsomanikis, and MO Andreae, Nitrous oxıde emissions from the Arabian Sea, Geophys. Res Lett., 23, 3175-3178, 1996.

Bange, H.W., T Rixen, A.M. Johansen, R L. Siefert, R Ramesh, V. Ittekkot, M R. Hoffmann, and M.O Andreae, A revised nitrogen budget for the Arabian Sea, Global Blogeochem. Cycles, in press, 2000 .

Bouwman, A F , K W Van der Hoek, and J.G J Olıvier, Uncertaintıes in the global source distribution of nitrous oxıde, J. Geophys. Res, 100, 2785-2800, 1995

Brandes, J.A, A.H. Devol, T Yoshinar, D.A Jayakumar, and S.W.A. Naqvi, Isotopic composition of nitrate in the central Arabian Sea and eastern tropical North Pacific. A tracer for mixing and nitrogen cycles, Limnol. Oceanogr., 43, 1680-1689, 1998.

Burkill, P.H (Ed.), Arabesque, UK JGOFS Process Study of the Arabian Sea, Deep Sea Res, Part II. 46, 529-863, 1999.

Burkill, P H., R.F.C. Mantoura, and N.J.P. Owens (Eds.), Biogeochemical cycling in the northwestern Indian Ocean, Deep Sea Res, Part II, 40, 643-849, 1993.

Butler, J.H, and J.W. Elkins, An automated technique for the measurements of dissolved $\mathrm{N}_{2} \mathrm{O}$ in natural waters, Mar. Chem., 34, 47-61, 1991 .

Butler, J H , J W. Elkins, T.M. Thompson, and K.B. Egan, Tropospheric and dissolved $\mathrm{N}_{2} \mathrm{O}$ of the West Pacific and Indian Oceans during the El Niño Southern Oscillation event of 1987, $J$ Geophys. Res., 94 $14,865-14,877,1989$.

Codispoti, L.A., and J.P. Christensen, Nitrification, denitrification and nitrous oxide cycling in the Eastern Tropical South Pacific, Mar. Chem , 16, 277-300, 1985 .

Codispoti, L.A., J.W. Elkins, T. Yoshinari, G.E. Friederich, C.M Sakamoto, and T T. Packard, On the nitrous oxide flux from productive regions that contain low oxygen waters, in Oceanography of the Indian Ocean, edited by B.N. Desai, pp. 271-284, A.A. Balkema, Brookfield, Vt., 1992

Cohen, Y., Consumption of dissolved nitrous oxide in an anoxic basin, Saanich Inlet, Britısh Columbia, Nature, 272, 235-237, 1978.

Cohen, Y., and L.I. Gordon, Nitrous oxide production in the ocean, $J$. Geophys Res., 84, 347-353, 1979.

Desal, B.N. (Ed ), Oceanography of the Indıan Ocean, 780 pp., A.A Balkema, Brookfield, Vt., 1992

De Wilde, H.P.J., and W Helder, Nitrous oxide in the Somalı Basin The role of upwelling, Deep Sea Res., Part II, 44, 1319-1340, 1997

Dore, J.E., B.N. Popp, D.M Karl, and F J. Sansone, A large source of atmospheric nitrous oxide from subtropical North Pacific surface waters, Nature, 396, 63-66, 1998.

Elkıns, J W., Determinatıon of dissolved nitrous oxide in aquatic systems by gas chromatography using electron capture detection and multi phase equilibration, Anal Chem., 52, 263-267, 1980. 
Elkins, J.W., S C Wofsy, M.B. McElroy, C.E. Kolb, and W.A. Kaplan, Aquatic sources and sinks for nitrous oxıde, Nature, 275, 602-606, 1978

Farrenkopf, A.M., G.W. Luther III, V.W. Truesdale, and C H. Van der Weijden, Sub-surface iodıde maxima: Evidence for biologically catalyzed redox cycling in the Arabian Sea OMZ during the SW monsoon, Deep Sea Res , Part II, 44, 1391-1409, 1997.

Froelich, P.N., G P Klinkhammer, M.L. Bender, N.A. Luedtke, G R Heath, D Cullen, P. Dauphin, D. Hammond, B Hartman, and V Maynard, Early oxidation of organic matter in pelagic sediments of the eastern equatorial Atlantic Suboxic diagenesis, Geochtm Cosmochim. Acta, 43, 1075-1090, 1979.

Gage, J.D., L.A. Levin, and G.A. Wolff (Eds), Benthic processes in the deep Arabıan Sea, Deep Sea Res, Part II, 47, 1-375, 2000

Hashimoto, L.K., W.A Kaplan, S.C. Wofsy, and M B McElroy, Transformation of fixed nitrogen and $\mathrm{N}_{2} \mathrm{O}$ in the Cariaco Trench, Deep Sea Res., Ser. A, 30, 575-590, 1983.

Ittekkot, V., and R R. Nair (Eds.), Monsoon Btogeochemistry, 200 pp., Selbstverlag des Geol.-Paläontologischen Inst. der Univ Hamburg, Hamburg, Germany, 1993.

Khalil, M.A.K., and R.A. Rasmussen, The global sources of nitrous oxide, J. Geophys. Res., 97, 14,651-14,660, 1992.

$\mathrm{Kim}, \mathrm{K} . \mathrm{R}$., and $\mathrm{H}$. Craig, Two-1sotope characterization of $\mathrm{N}_{2} \mathrm{O}$ in the Pacific Ocean and constraints on its origin in deep water. Nature, 347, $58-61,1990$.

Krishnaswami, S., and R.R. Nair (Eds.), Specıal Section: JGOFS (India), Curr. Scl., 71, 831-905, 1996.

Lal, D. (Ed ), Btogeochemistry of the Arabian Sea, 250 pp., Indian Acad. of Sci., Bangalore, 1994.

Lal, S., P.K. Patra, S Venkataramani, and M.M. Sarin, Distribution of nitrous oxide and methane in the Arabian Sea, Curr Scl., 71, 894899, 1996.

Law, C.S, and N.J.P. Owens, Significant flux of atmospheric nitrous oxide from the northwest Indian Ocean, Nature, 346, 826-828, 1990

Lee, C., et al., Particle organic carbon fluxes: Compilation of results from the 1995 US JGOFS Arabian Sea Process Study, Deep Sea Res., Part II, 45, 2489-2501, 1998.

Mantoura, R.FC, C.S. Law, N.J.P. Owens, PH. Burkill, EMS Woodward, R J.M. Howland, and C.A. Llewellyn, Nitrogen biogeochemical cycling in the northwestern Indian Ocean, Deep Sea Res., Part II, 40, 651-671, 1993.

McAllister, W.A, and W V Southerland, New use for a 0.5 -nanometer molecular sieve gas chromatography column, Anal Chem., 43, 1536. 1971

Morrison, J.M., L.A Codıspotı, S. Gaurin, B. Jones. V Manghnani, and $Z$. Zheng, Seasonal variation of hydrographic and nutrient fields during the US JGOFS Arabian Sea Process Study, Deep Sea Res., Part II, 45, 2053-2101, 1998.

Naqvi, S.W.A., Geographical extent of denitrification in the Arabian Sea, Oceanol Acta, 14, 281-290, 1991

Naqvi, S.W.A., Denitrification processes in the Arabian Sea, in The Biogeochemistry of the Arabian Sea, edited by D. Lal, pp. 181-202, Indian Acad. of Sci., Bangalore, 1994.

Naqvi, S.W.A., and R.J. Noronha, Nitrous oxide in the Arabian Sea, Deep Sea Res., 38, 871-890, 1991.

Naqvi, S.W.A., and M.S. Shailaja, Activity of the respiratory electron transport system and respiration rates within the oxygen minimum layer of the Arabian Sea, Deep Sea Res., Part II, 40, 687-695, 1993.

Naqvi, S.W.A., R.J. Noronha, M.S. Shailaja, K. Somasundar, and R. Sen Gupta, Some aspects of the nitrogen cycling in the Arabian Sea, in Oceanography of the Indtan Ocean, edited by B N. Desai, pp. 285311, A.A Balkema, Brookfield, Vt., 1992

Naqvi, S.W.A., D.A. Jayakumar, M. Nair, M.D. Kumar, and M.D. George, Nitrous oxide in the western Bay of Bengal, Mar. Chem, 47, 269-278, 1994

Naqvi, S.W.A., T. Yoshınarı, D A. Jayakumar, M.A.A Altabet, P.V Narvekar, A H. Devol, J.A. Brandes, and L.A. Codispoti, Budgetary and bıgeochemical implications of $\mathrm{N}_{2} \mathrm{O}$ isotope signatures in the Arabian Sea, Nature, 394, 462-464, 1998.

Nevison, C.D., R.F. Weiss, and D.J Erickson III, Global oceanic emissions of nitrous oxide, J. Geophys Res., 100, 15,809-15,820, 1995.
Olson, D.B , G.L Hitchcock, R.A. Fine, and B.A. Warren, Maintenance of the low-oxygen layer in the central Arabian Sea, Deep Sea Res., Part II, 40, 673-685, 1993.

Oudot, C, C Andrie, and Y. Montel, Nitrous oxide production in the tropical Atlantic Ocean, Deep Sea Res., 37, 183-202, 1990.

Patra, P.K., S. Lal, S. Venkataramani, S.N. De Sousa, V.V.S.S. Sarma, and $\mathrm{S}$. Sardesai, Seasonal and spatial variability in $\mathrm{N}_{2} \mathrm{O}$ distribution in the Arabian Sea, Deep Sea Res., Part 1, 46, 529-543, 1999.

Pierotti, D., and R.A. Rasmussen, Nitrous oxide measurements in the eastern tropical Pacific Ocean, Tellus, 32, 56-72, 1980.

Prather, M., R. Derwent, D. Ehhalt, P. Fraser, E. Sanhueza, and X. Zhou, Other trace gases and atmospheric chemistry, in Climate Change 1995, The Science of Climate Change, Contribution of Working Group I to the Second Assessment of the Intergovernmental Panel on Climate Change, edited by J T. Houghton et al, pp. 86-103, Cambridge Unıv. Press, New York, 1996.

Rao, T.S.S., and R.C. Griffiths, Understanding the Indian Ocean, Perspectives on oceanography, 187 pp., United Nations Educ., Sci. and Cult. Org (UNESCO), Paris, 1998.

Rheın, M., L Stramma, and O. Plahn, Tracer signals of the intermediate layer of the Arabian Sea, Geophys. Res. Lett., 24, 2561-2564, 1997.

Ronner, U., Distribution, production and consumption of nitrous oxide in the Baltic Sea, Geochim. Cosmochim. Acta, 47, 2179-2188, 1983.

Schott, F.A., J. Fischer, U. Garternicht, and D. Quadfasel, Summer monsoon response of the northern Somali Current, 1995, Geophys. Res. Lett , 24, 2565-2568, 1997.

Shenoi, S S C., S.R Shetye, A.D. Gouveia, and G.S Michael, Salınity extrema in the Arabian Sea, in Monsoon Blogeochemistry, edited by V Ittekkot and R.R. Nair, pp. 37-49, Selbstverlag des Geol.Paläontologischen Inst. der Univ. Hamburg, Hamburg, Germany, 1993.

Siedler, G., and H. Peters, Properties of sea water, in Landolt-Börnstein, Oceanography. New Ser., Group V, vol 3a, edited by J. Sundermann, pp. 233-264, Springer Verlag, New York, 1986

Smith, S L. (Ed.), The 1994-1996 Arabian Sea expedition: Oceanic response to monsoonal forcing, Part 1, Deep Sea Res, Part II, 45 , 1905-2501, 1998

Smith, S.L (Ed.), The 1994-1996 Arabian Sea expedition: Oceanic response to monsoonal forcing, Part 2, Deep Sea Res., Part II, 46, 1531-1964, 1999.

Stumm, W., and J.J Morgan, Aquatic Chemistry, 1022 pp., John Wiley, New York, 1996

Upstill-Goddard, R.C., J. Barnes, and N.J.P. Owens, Nitrous oxide and methane during the $1994 \mathrm{SW}$ monsoon in the Arabian Sea/northwestern Indian Ocean, J. Geophys. Res., 104, 30,06730,084, 1999

Van Weerıng, T.C.E., W. Helder, and P. Schalk (Eds.), Netherlands Indian Ocean Program 1992-1993: First results, Deep Sea Res., Part II , 44, 1177-1480, 1997.

Weiss, R.F., The solubility of nitrogen, oxygen and argon in water and seawater, Deep Sea Res., 17, 721-735, 1970

Weiss, R.F., and B.A Price, Nitrous oxide solubility in water and seawater, Mar. Chem., 8, 347-359, 1980

Yoshida, N, H. Morimoto, M. Hirano, I. Koike, S Matsuo, E. Wada, T Saino, and A Hattori, Nitrification rates and ${ }^{15} \mathrm{~N}$ abundances of $\mathrm{N}_{2} \mathrm{O}$ and $\mathrm{NO}_{3}{ }^{-}$in the western North Pacific, Nature, 342, 895-897, 1989.

Yoshinari, T., Nitrous oxide in the sea, Mar. Chem., 4, 189-202, 1976.

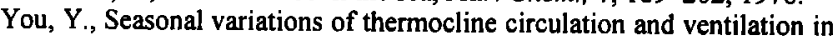
the Indian Ocean, J. Geophys. Res., 102, 10,391-10,422, 1997.

M. O. Andreae and H. W. Bange, Biogeochemistry Department, Max Planck Institute for Chemistry, P.O. Box 3060, D-55020 Mainz, Germany. (bange@mpch-mainz.mpg.de)

S. Rapsomanikis, Laboratory of Atmospherıc Pollution Science and Technology, Environmental Engineering Department, Demokritos University of Thrace, GR-67100 Xanthi, Greece.

(Received May 19, 1999; revised August 1, 2000; accepted August 23, 2000.) 